\title{
Dijital Oyunlarda Oynanış ve Anlatı İlişkisi: DayZ Oyunu ve Village Topluluğu
}

\author{
Yavuz Demirbaş \\ Araştırma Görevlisi Doktor \\ Marmara Üniversitesi \\ Illetişim Fakültesi \\ yavuz.demirbas@marmara.edu.tr \\ Orcid: 0000-0003-2424-7203
}

\begin{abstract}
The Relation of Gameplay and Narrative in Video Games: DayZ Video Game and Village Community

The relation between game narrative and game form is a subject that has provoked protracted discussion in game studies. As an approach and a set of methods proposed by this approach, ludology makes a distinction between games and other media and focuses on game form. Theoretical discussions in game studies need to be supported by the analyzes of the examples taken from the games themselves. This study examines how the narrative of DayZ is constructed by conducting a game-formal analysis. To this aim, the study focuses on the concept of gameplay, which is connected to the development process, gameworld, story, technical base, and game mechanics of the game. Another element that completes the gameplay is the set of player actions in the game. The ethnographic methods of digital play have been used to discuss how players create their own stories. The Village community was taken as an example to work on the player's culture and productions. While contemporary research frequently chooses to handle the theme of violence in digital games, this paper underlines different dimensions of meanings emerging from gameplay by elaborating on the productions of DayZ communities, which shows solidarity, co-operation, and friendship.
\end{abstract}

keywords: Digital game, new media, cyber ethnography, ludology, narrative 


\section{Résumé}

\section{La relation entre le gameplay et la narration dans les jeux numériques: le jeu DayZ et la communauté Village}

Dans les études des jeux, la relation entre la forme du jeu et les narration du jeu est un sujet qui a provoqué des discussions prolongées. La ludologie, prenant en compte les différents aspects des autres moyens de communication, est une approche focalisée sur la forme du jeu et un ensemble de méthodes proposées par cette approche. Dans les études des jeux, les discussions théoriques doivent être soutenues par des analyses des exemples pris dans des jeux eux-mêmes. En faisant une analyse de la forme du jeu, cette recherche examine comment la narration du jeu de DayZ est établi. Dans le cadre du concept de gameplay, le focus est porté sur le processus de développement, sur le monde, la narration, l'infrastructure technologique et les mécanismes du jeu DayZ. L'ensemble des actions des joueurs dans le jeu est un autre élément qui complète le gameplay. Les méthodes ethnographiques du jeu numérique ont été utilisées pour discuter la manière par laquelle les joueurs créent leurs propres histoires. La communauté Village a été prise comme exemple afin de travailler sur la culture et les productions du joueur. Tandis que de nos jours les elements de la violence visuelle rencontrés dans les jeux digitaux font fréquemment partie des recherches, cette recherche souligne les différentes dimensions des sens apparus au cours du temps qu'on joue, en se tournant surtout vers les productions communes composées de solidarité, de coopération et d'amitié.

mots-clés: Jeu numérique, nouveau média, cyber ethnographie, ludologie, narration

\section{Öz}

Oyun çalışmalarında oyun biçimi ve oyun anlatılarının ilişkisi uzun süren tartışmalara neden olmuş bir konudur. Ludoloji, oyunların diğer iletişim araçlarından farklı yönlerini göz önünde bulundurarak, oyun biçimini merkeze alan bir ekol ve bu ekolün önerdiği yöntemler bütünüdür. Oyun çalışmalarındaki kuramsal tartışmaların, somut oyun örneklerinin analizi ile desteklenmesi gerekmektedir. Bu çalışmada DayZ oyununun oyun biçimsel bir analizi yapılarak oyun anlatısının nasıl kurulduğu incelenmektedir. Oynanış kavramı çerçevesinde DayZ'nin geliştirme süreci, oyun dünyası, öyküsü, teknolojik altyapısı ve oyun mekaniklerine odaklanılmaktadır. Oynanışı tamamlayan diğer bir unsur da oyuncuların oyun içindeki eylemleridir. Oyuncuların kendi öykülerini nasıl oluşturdukları ele alınırken, dijital oyun etnografisi yöntemlerinden faydalanılmıştır. Oyuncu kültürü ve üretimleri için örnek olarak Village topluluğu alınmıştır. Dijital oyunlarda görsel şiddet öğelerinin en sık ele alınan araştırma konusu olduğu günümüz şartlarında, bu çalışma DayZ oyunu çevresindeki toplulukların yardımlaşma, iş birliği ve dostluk içeren ortak üretimlerine yönelerek oynanışta ortaya çıkan anlamların farklı boyutlarının da alını çizmektedir.

anahtar kelimeler: Dijital oyun, yeni medya, siber etnografi, ludoloji, anlatı 


\section{Giriş}

Oyun çalışmaları, medya çalışmaları kapsamında ele alabileceğimiz ancak bağımsız yönleri de bulunan, bilgisayar oyunlarını merkeze alan bir literatür sunmaktadır. Oyun çalışmaları yazınının en önemli tartışma konularından biri oyun ve anlatı ilişkisi olmuştur. Dijital oyunların anlatı perspektifinden ele alınmasında oyun biçimine özgü öğelerin merkezde tutulması gerektiğini savunan ludoloji' yöntemi, prosedürel ${ }^{2}$ olarak işleyen oyun anlatılarının analizi için yeni kavramsal araçlara olan ihtiyacı karşılamaya yönelmiştir. Öte yandan oyunlara yönelik yeni medya yaklaşımlarına eleştirel bakılmakta, yöntem ve sonuçları kısmen reddedilmektedir. Bu tartışmanın kuramsal boyutu yerel çalışmalarda da ele alınmış (Karadeniz, 2017; Demirbaş, 2017) ve bir oranda tüketilmiş bulunmakla birlikte, somut oyun örneklerinden beslenen ve bu örnekleri oyun biçimi açısından ele alan çalışmalar oldukça kısıtıdır.

Dijital oyun anlatılarına dair çalışmaların sadece kuramsal değil pratik sonuçları da bulunmaktadır. Türkiye'de ve dünyada medyanın oyunları ele alış biçimi, eğitimde oyunun rolü ve yasa yapma pratiklerinde dijital oyunlara yönelik negatif bir bakış olduğu görülmektedir. Dijital oyunlar; bağımlıık, şiddet ve asosyal davranışla ilişkilendirilmektedir. Akademik çalışmalarda da oyun anlatıları ele alınırken özellikle şiddet temsillerine odaklanılmaktadır (Yengin, 2012). Oyun ve şiddet ilişkisinin gerçekliğinin somut örnekler üzerinden ele alınması, şiddet temsilleri kadar oyun biçimine dair diğer özelliklerin de yer aldığı derinlikli analizler yapılması gerekmektedir.

Bu makalede, oyun çalışmalarının ana tartışmalarından biri olan oyun biçimi ile anlatı ilişkisinin nasıl kurulduğu meselesi oynanış3 (gameplay) kavramı çerçevesinde DayZ (Bohemia Interactive, 2018) bilgisayar oyunu örneği üzerinden ele alınacaktır. Oyunun ortaya çıkardığı anlamlar, ancak oynanış esnasında, yani oyun sistemi ile oyuncu iliş̧kiye geçtiğinde, bu ilişki içinde ne ifade ettikleri ile değerlendirilebilir (Aarseth, 2003). Oynanışın analiz edilmesi ise beraberinde oyunun ger-

1 Ludoloji, bilgisayar oyunları üzerine yapılan akademik çalışmaların kurucu ekolünün adıdır. Ayrıca bazı metinlerde oyun çalışmaları yerine de kullanılmaktadır. Yine bazı araştırmacılar açısından ludoloji, bir yöntemler bütünü olarak düşünülmektedir. Ludolojinin temel yaklaşımlarından biri oyunların kendine özgü yönlerinin, oyun biçiminin merkeze alınmasıdır. Oyun biçimini incelerken oyunun kuralları, oyunun amacı, oynanış, oyun durumu, oyun mekanikleri vb. öğelere odaklanılmaktadır.

2 Prosedürellik, kod tabanlı, programlanabilir medya sistemlerinin çok sayıda öğeyi farklı durumlar içinde, algoritmalarla, modüler olarak üretebilmesini ve sunabilmesini sağlamaktadır. Dijital oyunlarda kurallar programlanmış prosedürler ile icra edilir, oyun dünyası yine benzer şekilde oyuncuya sunulur. Bilgisayarların devreye girmesiyle normalde oyuncular tarafından hesap edilemeyecek ve akılda tutulamayacak kuralların, dolayısıyla da oldukça karmaşık oynanış imkânlarının önü açılmışır.

3 Oynanış (gameplay); oyun dünyası, oyunun materyal sistemi (donanım ve yazılım) ve oyuncu arasındaki ilişkide, oyunun oynanma sürecinde meydana gelen bütünlük ve bunun sonucunda ortaya çıkan oyuncu deneyimidir. Oynanış merkezli yaklaşımlara göre farklı oyun katmanlarından yalnızca birinin analizi, oyunun işlerken ürettiği anlamları ortaya çıkarmak için yeterli değildir. Bu kavram akademik literatürde yer almakla birlikte, dijital oyun incelemeleri ve eleştirilerinde de kullanılmaktadır. 
çekleştiği oyun dünyası ${ }^{4}$ (game world), oyunun yapısı, oyuncu kültürü, teknolojik altyapı ve bunun geliştirme sürecinin incelenmesini getirmektedir.

DayZ, kitlesel çevrimiçi (MMO: Massively Multiplayer Online) ${ }^{5}$ bir bilgisayar oyunudur. Oyun mekanikleri' (game mechanics) (Jarvinen, 2009) açısından bakıldığında hayatta kalma oyunları ve rol yapma oyunlarının ${ }^{7}$ bazı özellikleri ile silahlı çatışma içeren FPS ${ }^{8}$ (First Person Shooter) oyunlarının özelliklerini bir araya getirmektedir. Oyunda rakip olarak diğer oyuncular ve bilgisayar kontrolündeki zombiler yer almaktadır. Diğer oyuncularla olan ilişkiler çatışmayı olduğu kadar yardımlaşmayı da içerebilmektedir. Öyle ki oyunun ana unsurunun bu ilişkilerin dinamik yapısı olduğu söylenebilir. DayZ ilk olarak gerçekçi savaş ortamları sunan ARMA 2 (Bohemia Inveractive, 2009) oyununun ve daha sonra eklenen ARMA 2: Operation Arrowhead (Bohemia Inveractive, 2010) eklenti paketinin ${ }^{9}$ Dean Hall tarafından modifiye ${ }^{10}$ edilmesi ile ortaya çıkmıştır. Oyun daha sonra tek başına bir ürün olarak yeniden tasarlanarak satışa sunulmuştur.

\section{DayZ'yi benzerlerinden ayıran, oyun mekanikleri sınırlandırılmamış PvP}

4 Oyunun gerçekleştiği uzamı belirtirken, 2 boyutlu grafiklere sahip oyunlar için seviye ve harita kavramları, 3 boyutlu oyunlarda ise genelde oyun dünyası kavramı kullanılmaktadır. Örneğin, World of Warcraft (2004) oyununun oyun dünyası Azeroth sanal oyun dünyaları arasında en bilinir olanlardan biridir. Oyun araştırmalarında veya internet metinlerinde kimi zaman harita ve oyun dünyası kavramlarının yer değiştirilebilir olarak kullanıldığı görülmektedir.

5 Kitlesel Çevrimiçi Oyunlar (MMO veya MMOG); çok sayıda oyuncunun çevrimiçi sunuculara bağlanarak oldukça geniş oyun dünyalarında bir arada oynadığı bilgisayar oyunlarıdır. Çok oyunculu (multiplayer) oyunların bir bölümü ev veya işyeri ağları gibi yerel ağlarda (LAN) çalışmak üzere düzenlenmiştir. Diğer bir yöntem de internet üzerinden az sayıda oyuncuyu, bu oyunculardan birinin bilgisayarı sunucu işlevi görecek şekilde buluşturmaktır. Takım mücadelesine dayanan bazı oyunlar sunucuya bağlanmayı gerektirse de az sayıda oyuncuyu kısıtlı oyun mekânlarında konuk etmektedir. Kitlesel çevrimiçi oyunlarında ise, oyuncu sayısı diğer örneklerden fazladır, sunucu veya sunuculara bağlantı sağlanır ve ayrıca oyun dünyaları daha büyüktür. Ayrıca genelde bu oyunlarda oyuncunun oyun dünyasına müdahaleleri kalıcıdır (persistent). MMO oyunları oynanışın türüne (genre) göre MMORPG, MMORTS veya MMOFPS gibi isimlerle de anılabilmektedir.

6 Oyun mekanikleri (game mechanics) oyun tarafından sunulan, kodlanmış ve kuralı yapılardır. Örneğin, satranç oyunu taşların yer değiştirmesi, birbirinin yerine gelerek diğer taşları yemesi, hamle sonrası tur (turn) geçme gibi mekanikler içermektedir. Bilgisayar oyunlarında kurallar ve katmanları ayrı ele almak gerekmektedir. Bilgisayar oyunlarında kurallar oyun programında işleyen mekanikler olarak entegre edildiğinden, arada programlamanın dolayımından geçen bir ilişki bulunmaktadır.

7 Rol yapma oyunları (RPG: Role-playing games), aslında bilgisayardaki örneklerinden önce masa başında oynanan, oyuncular tarafından yaratılan çeşitli karakterlerin oyun yöneticisinin kontrolünde bir öykü içinde canlandırılığı oyunlardır. Bu oyun türü daha sonra bilgisayar oyunları formunu da almıştır.

8 Birinci şahıs nişancı (FPS: First person shooter), kameranın oyun karakterinin gözünden görecek şekilde (öznel kamera) konumlandığı, silahlı çatışmaya dayalı oyunlardır.

9 Eklenti paketi, ana oyuna yeni görevler, haritalar, araçlar ekleyerek oyunu zenginleştiren ve ana oyundan ayrı olarak satılan ürünlere denmektedir.

10 Modifikasyon veya mod'lama (modification, modding), bilgisayar oyunlarının oyuncular tarafından yeni özellikler içerecek şekilde dönüştürülmesi, yeniden tasarlanması ve programlanması faaliyetidir. Kısmi bir şekilde gerçekleşebileceği gibi yeni bir oyunun ortaya çıkmasını sağlayacak şekilde tümden bir modifikasyona gidilmesi de mümkündür. Modifiye edilmiş oyunlar, ana oyuna ait oyun motorunu, teknolojik altyapıyı büyük ölçüde korurken, farklı oyun dünyaları ve oynanış (gameplay) öğeleri eklerler. Modifiye edilmiş oyunlar gerekli izinler sağlandığında kendi başına farklı bir oyun olarak da satışa sunulabilmektedir. 
(Player versus Player) ${ }^{11}$, hayatta kalma (survival), kalıcı ölüm (perma-death) ve konum bazlı sesli konuşmadır. Bu dört farklı mekaniğin özgün bir kombinasyonu ile DayZ'nin durmaksızın çalışan bir sahneleme-öyküleme aracı olarak nasıl işlediğine bakmak bilgisayar oyunlarının geneli için de önemli bilgiler sunacaktır. Bilgisayar oyunları tasarlanabilir şeyler olmakla birlikte, oynanış tepeden aşağı tasarlanabilir bir süreç veya yapı değildir. Oyuncuya açıklı̆ı oranında değişen ve gelişen bir yapıdadır. Bazı durumlarda tasarımdaki hatalar (bug, glitch) bile, bunlar üzerinden anlamlar üretilmesine olanak tanımakta ve oyuncu tarafından sahiplenilerek oynanışa ve dolayısıyla oyunun anlatısına geri katılmakta, teknik bir detaydan oyunun ürettiği bir ifadeye dönüşmektedir.

Bu doğrultuda DayZ'de oynanışın özgünlüğünü sağlayan unsurların izi sürülecektir. Bunlardan ilki olan geliştirme sürecindeki farklılıklar, oyunun oyuncu topluluklarının deneysel pratiklerine açıklığını sağlayan bir etkendir. Oynanışı etkileyen bir bileşen olarak oyun dünyası (gameworld) ele alındığında, DayZ'nin oyun dünyası Chernarus'un, oynanışı rol yapma (roleplay) davranışını ortaya çıkaracak şekilde etkilediğini görmekteyiz. Oyunun teknolojik altyapısının el verdiği gece/ gündüz döngüsü gibi özelliklerin oynanışta oldukça karmaşık sonuçların ortaya çıkmasını sağlamaktadır. DayZ oyuncuların kendi öykülerini yaratmasını sağlamakla birlikte, tasarımında oyunun öyküsü olarak nitelendirmekte zorlanacağımız minimal bir içerik sunmaktadır. Öte yandan oyunun oynanışında ortaya çıkan anlamlar oldukça zengindir ve oyuncuların hafızalarında yaşadıkları maceraların her biri birer küçük öykü olarak berrak bir şekilde yer almaktadır. Bu noktada oyun çevresindeki oyuncu topluluğuna bakılacak ve oynanış ile oyuncu kültürünün dinamik ilişkisinde oyun anlatılarının nasıl kurulduğu incelenecektir. Bu kısımda çaış̧manın odağında Village isimli oyuncu topluluğu olacaktır.

\section{Yöntem}

Üzerinde başka çalışmalarda geniş bir şekilde durulmuş olan oynanış kavramı ve arkasındaki ludoloji literatürü, oyunu oyun sistemi ile oyuncu arasındaki dinamik ilişki olarak analiz etmek için kavramsal araçlar sunmaktadır. Bu doğrultuda oyunun prosedürel yapısı, oyun mekanikleri, oyunun kuralları, hedefleri ve değişen oyun durumunu ${ }^{12}$ (Juul, 2005) oyuncu eylemleriyle birlikte ele almak gerekmektedir. Oyun çalışmalarında araştırmacının aynı zamanda oyuncu olması yeğlenmektedir. Oynayarak analiz (Aarseth, 2003) yöntemi oynanışın incelenmesinde başat yöntemlerden biridir. Aarseth'e göre: "Eğer oyunu kişisel olarak deneyimlememişsek,

11 Oyuncu oyuncuya karşı (PvP: Player versus Player) Çevrimiçi oyunlarda oyuncunun rakiplerine dair konfigürasyon PvE (Player versus Environment) veya PvP olarak belirlenmektedir. PvE oyuncunun oyun dünyasındaki sanal karakterlerle mücadelesini içerirken, PvP oyuncuların birbirlerine karşı mücadelesidir.

12 Oyun durumu (game state) bir oyundaki öğelerin güncel yapılanışıdır. Örneğin, bir satranç oyununda üzerindeki taşlar ile satranç tahtasının son hali bir oyun durumudur. Oyun durumu satrançta oluşabilecek bütün olasılıkların evreninde sadece bir olasılığa denk gelmektedir. Oyuncular eylemleri ile tahtayı düzenleyerek başka oyun durumlarına geçiş yaparlar. Masaüstü satrançta oyun durumu tahtanın öylece bırakılması ile saklanırken, bilgisayarda oynanan oyunlarda sayısallaştııılarak kaydedilir ve böylece yarıda kalan oyunlara devam etmek mümkün olur. 
oyun mekaniklerini ne kadar çalışsak ve iç işleyişlerini tahmin etmek için ne kadar çabalasak da ciddi hatalar yapma eğiliminde oluruz"13 (Aarseth, 2003, s. 3).

Ludoloji, farklı araştırmacılar için farklı anlamlar ifade etmektedir. Bu doğrultuda iki ayrı katmanı işaret etmek gerekmektedir: yaklaşımlar ve metotlar. Ludolojik metotlar, oyun mekaniklerinin, kuralların, oyun bileşenlerinin incelenmesi gibi farklı başlıklar altında ele alınabilir ve bulgular üzerinde konuşulabilir. Öte yandan yaklaşımlar açısından bakıldığında ludolojinin katı ve yumuşak versiyonları olduğu görülmektedir. Örneğin, Eskelinen (2001) oyunların anlatı olarak incelenemeyeceğini, oyun öyküsüne süs olarak bakılabileceğini katı bir şekilde ileri sürmüştür. Eskelinen'in "katı ludoloji" yaklaşımına kıyasla Frasca (2001) dijital oyunları farklı toplumsal durumların temsil edilmesi, sahnelenerek değerlendirilmesi açısından ele alarak potansiyel bir toplumsal dönüşümün aracı olarak da görmektedir. Klevjer'e (2002) göre oyun çalışmalarının tümü ludoloji olarak adlandırılabilir ve oyunlara özgü nitelikleri araştırmakta problem bulunmamaktadır. Ancak Klevjer, Eskelinen'in anlatı karşıtlığını "radikal ludoloji" olarak görerek karşı çıkmaktadır. Bu görüş farklılıkları ludolojinin üzerinde tamamen ortaklaşımış bir yaklaşım olarak değerlendirilemeyeceğini göstermektedir. Ortak noktalar değerlendirildiğinde, ludolojinin oyun biçimini incelemeye yönelen yöntemleri içeren bir çatı işlevi gördüğü söylenebilir.

Dijital oyunlar, oyun endüstrisi ürünleri veya bağımsız birey veya grupların ürettikleri yazılımlar olduklarından, bu yazılımların görsel temsil olarak sunduğu sanal oyun dünyaları Juul'ün (2005) kural temelli oyun tanımı dışında öğeler de barındırabilmektedir. Aarseth'e (2003) göre dijital oyunlardan ziyade, sanal oyun ortamları içinde oynanan oyunlardan bahsetmek mümkündür. Bir anlamda günümüz oyun üretimi, içinde oyun oynanabilecek sanal uzamların ve bunu sağlayan materyal temelin üretimidir. Bu ortamlar içlerinde klasik anlamıla birden fazla kurallı veya serbest oyun biçimi içerebilir, oyuncular kendi oyunlarıyla bu ortamları zenginleştirebilir veya tam tersine ortada oyunun izi bile olmayabilir.

Bu çerçevede dijital oyunların analizi kural temelli oyun dışında kalan öğeleri de içermek durumundadır. Bu çalışma kendi ludoloji okumasını ve metotlarını güncel oyun çalışmaları literatürüne dayandırmakla birlikte, yaklaşımını daha eski bir kaynaktan, Huizinga'nın (1970) kültürel anlamı ve işleyişiyle oyun çerçevesinden kurmaktadır. Ludoloji, oyunların kural temelli sistem olarak altyapısına, karşı çıktığı yeni medya kuramları da dijital oyunların etkileşim temelli teknolojik altyapısına eğilirken, oyunların tarih öncesinden beri kültürel müşterekler olarak varlıklarına körleşmektedir (Demirbaş, 2017). Oyunlar, hem belirli bir üretimin sonucu olarak, yukarıdan aşağıya, tasarlanmış yapılar, hem de aşağıdan yukarıya, oyuncu kültürünün ürünü, oyuncuların kendi deneyimlerinin ve eylemlerinin bir parçası olarak tanımlanabilir. DayZ incelenirken oyun (game) kadar oynama süreci ve eylemi (play) de göz önüne alınacak ve oynanış (gameplay) kavramı çerçevesinde bir analiz sunulacaktır.

13 Yazar tarafından çevrilmiştir. 
Bu makalede anlatı kavramı çeşitli oyuncu öyküleri, oyuncu kültüründe yer eden oyun içinde gerçekleşen olaylar, grupların kendi iç tarihleri ve efsaneleri, üretilen diğer anlamlar gibi öğelerin oluşturulma biçimini, bunları üreten mekanizmaları işaret edecek şekilde geniş anlamda kullanılmıştır. En dar anlamıyla kullanıldığı durumlarda ise DayZ'nin öyküsü olarak ifade edilecektir. DayZ oynanışı ile anlatı ilişkisi ele alınıken Aarseth'in (1997, s. 21) metinsel makine (textual machine) kavramına paralel bir yaklaşım tercih edilmektedir. Aarseth'e (1997) göre oyunlar oynama anında oyuncu ve oyun aracının yapısı arasındaki karşııklı ilişkide anlam üreten mekanizmalardır. Oyunun dünyası, oyuncu, oyunun materyal tabanı gibi öğelerin birlikteliği içinde oyun performatif olarak işlemektedir. Öte yandan tasarımcı, üretici, geliştirici ve sorumlu diğer birey ve gruplar da bu sürece doğrudan veya dolaylı olarak etki

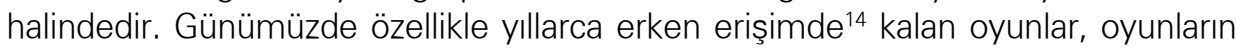
piyasaya sürülmesi sonrası eklentiler, çevrimiçi olanlarının yaşam süresi boyunca yapılan müdahaleler, moderatörler, adminler, içerik üreticileri ve daha pek çok farkı aktör söz konusuyken, oyunların hem yapısının hem oyuncularının oldukça değişken olduğu bir gerçektir. Bu yenilikler bir milat gibi ele alınmak zorunda değildir, çünkü tarihsel olarak bakıldığında dijital oyunlardan önce de farklı kültürlerin farkı oyunları benimseyip dönüştürdüğünü, bunların çevresinde farklı etki gruplarının kurulduğunu da görebilmekteyiz. Bu doğrultuda, DayZ bir metinsel makine olarak düşünülürken, belirli bir süreç boyunca var olan halinin oynanışı, bunun anlatı olarak karşılığı ve oyuncu kültürüyle etkileşimi ele alınacaktır.

DayZ örneğinde, karakterin sağlık durumu, intiyaçlar ve hastalıklar gibi çok sayıda parametrenin oyun içindeki işleyişini anlayabilmenin ve bu parametrelerle birlikte kurulan hayatta kalma eksenli oynanışın yarattığı oyuncular arası eylemleri anlamlandırabilmenin ilk elden kaynağı araştırmacının kendi çevrimiçi oyun deneyimidir. Bu doğrultuda oyunun 5 yıllık erken erişime açık geliştirme süreci ve sonrasında, oyun dünyasında toplam 1700 saat geçirilmiştir.

Tek oyunculu oyunlar (singleplayer) için oynayarak analiz önem taşırken, çok oyunculu oyunlarda oyun ortamı oyun yazııımının sınıları dışına taşmaktadır. Oyuncu bir topluluk üyesi olarak var olur ve oyunun bilgisi oyun dışı farklı kanallarla da iletilir. Bu doğrultuda araştırmacının alanın yerlisi olması gereği doğmakta, oyuncu kültürüne yönelirken siber etnografinin (sanal etnografi (Hine, 2000) ve netnografi (Kozinetz, 2010) gibi farklı adlarla da anılmaktadır) araçlarına da başvurulması gerekmektedir. DayZ ve oyuncu topluluğu, çevrimiçi oyun olarak World of Warcraft (2004) oyunu ile kıyaslanabilecek niteliktedir ve bu oyun geçtiğimiz yıllarda benzer metotlar ile incelenmiştir (Glas, 2010). Everquest (1999) oyununda hem araştırmacı hem oyuncu olarak bulunan Taylor'ın (2009) dijital oyun etnografisi yaklaşımının da bu çalışmayla paralellikleri vardır.

14 Erken erişim (early access), oyunun son haline gelmeden kullanıma açılmasıdır. Bu sayede oyun şirketleri oyuncuları tasarım sürecine dahil etmekte, onlardan gelen geri dönüşlerle oyuna yeni özellikler eklemektedir. Erken erişim, özellikle küçük çaplı oyun firmalarına oldukça uzun sürebilen ve maddi sıkıntılara gebe olan oyun geliştirme sürecinin erken bir aşamasında kaynak yaratma imkânı da sağlamaktadır. 
Bu çalışmada katılımcı gözleme başvurulmuştur. Bu yönteme uygun olarak, araştırmacının kendi oyun pratikleri kadar, diğer oyuncuların oyun eylemlerinin gözlemlenmesi de çalışmaya katkı sağlamıştır. Oyuncularla oyun içinde ve dışında, sesli ve metin bazlı görüşmeler yapılmıştır. Steam platformu ve Discord sunucuları üzerinden mesajlaşmalar, forum yazıları ve topluluğun twitch.tv ve Youtube gibi kanallar üzerinden yaptığı oyunla ilişkili kültürel üretimler incelenmiştir. Oynayarak analiz yöntemini besleyecek şekilde oyuna ait dokümanlar, tasarımcıların Twitter hesaplarından oyunla ilgili paylaşımları, üretici firma Bohemia Interactive'in çevrimiçi canlı yayınları ve bu kategoriler altında yer almayan başka çevrimiçi kaynaklara başvurulmuştur.

Araştırmanın bir parçası olarak DayZ topluluk sunucularından biri olan Village sunucusunda Village Guards topluluğuna katıınmıştır. Grup üyeleri araştırma konusunda bilgilendirilmiş ve rızaları alınmıştır. Oyuncuların gerçek kimlikleri halihazırda oyun içinde takma isimler kullanıldığından gizlidir, bu çalışmada da gerek duyulduğu yerlerde bu isimler kullanıldığından gizli kalacaktır.

DayZ literatüründe oyundaki çeşitli mekanikler ve temsilleri ele alan çalışmalar bulunmaktadır. Bu çalışmalarda oyunun kalıcı ölüm gibi mekanikleri üzerinde durulmuş (Carter vd. 2012 ve 2013; Allison vd. 2015), anlatıdaki bazı öğeler incelenmiş (Bø, 2013), oyundaki zombi temsiline odaklanılmış (Backe ve Aarseth, 2013), oyunun Hollywood anlatıları ile zıtlığına vurgu yapılmış (Schmeink, 2013) ve oyuncu eylemlerinin ahlaki boyutu (Cristofari ve Guitton, 2014; Carter ve Allison 2019) araştııılmıştır. Oynanışı belirleyen öğeler ile oyuncunun oynama edimi ilişkilendirilmekle birlikte, oyun çevresindeki toplulukların medyalar arası (transmedia) boyutu da olan kültürel üretimini oyun anlatısının bir parçası olarak inceleyen çalışma bulunmamaktadır.

\section{DayZ'nin Geliştirme Sürecinin Oynanışa Etkisi}

DayZ'nin tasarımcısı Dean Hall, askeri geçmişi olan bir ARMA 2 oyuncusudur. Ordudaki deneyimlerini askerlerin eğitiminde kullanılacak bir simülasyona dönüştürmek istemiştir. Bu isteğine ordudaki üstleri tarafından ilgi gösterilmeyince tasarladığı simülasyona zombiler ekleyerek kendi başına yayınlamaya karar vermiştir. Bu doğrultuda ARMA 2 oyunu üzerinde işleyen bir modifikasyon olarak DayZ'yi geliştirir (Harman, 2012). Ortaya oldukça zorlayıcı, oyuncunun beklentileriyle oynayan, sabrını sınayan farklı bir oyun çıkar.

DayZ'nin oyun modu olarak ilk hali, Bohemia Interactive'in geliştirdiği ARMA 2 oyununun ve ARMA 2: Operation Arrowhead paketinin ayrı ayrı satın alınması ve kurulmasını gerektirmektedir. Pek çok oyun modu gibi, ana oyuna çok sayıda yeni özellik eklenmiştir. Bu eklemeler ana oyunun kodunun da değiştirilmesini gerektirdiğinden, ortaya çıkan sentez aksaklık ve hatalara neden olabilen bir yapıdadır.

DayZ'nin mod olarak popülerliği, bu oyunun Çek Cumhuriyeti merkezli üretici firması Bohemia Interactive'i DayZ'yi kendi başına bir oyun olarak üretmeye teş- 
vik etmiştir. Mod'un yaratıcısı Hall'ü kadrosuna alan firma, öncelikle Şubat 2013'te ARMA 2: DayZ Mod ismiyle mod'u resmi olarak yayınlamıştır. Aralık 2013'te ise DayZ Standalone (buradan itibaren DayZ olarak kısaltılacaktır), kendi başına bir oyun olarak daha alpha ${ }^{15}$ aşamasındayken erken erişime ve satışa açımıştır. Steam çevrimiçi satış platformuna dahil edilen oyunun 2018 yılına kadar 4 milyondan fazla kopyası satılmıştır (Jones, 2018). Oyunun tam sürümü 5 yıllık bir geliştirme sürecinin ardından 13 Aralık 2018'de yayınlanmıştır.

Erken erişim, oyunların geliştirmesinde farklı etkilere açık bir süreçtir. DayZ örneğinde, oyun modunun oyuncuları, mod'da olan özelliklerin hepsinin yeni oyunda da olmasını beklemektedir. Yeni oyunu satın alan oyuncular, oyunun mod olarak geçmişinden kısmen habersiz, içerdiği özelliklerden çok, tam ve hatasız bir oyuna en kısa zamanda ulaşmayı önemsemektedir. Oyun geliştiricileri farkı beklentileri uzlaştırmak ve zamana karşı yarışmak durumundadır. Tasarımcı ise yaratıcı ve deneysel fikirleriyle yenilikçi bir oyun ortaya çıkarma niyetindedir.

DayZ'nin çok aktörlü geliştirme süreci, oyunun kendisini bir mücadele alanına dönüştürmüştür. Geliştirici firma Bohemia Interactive beklenen özellikleri ekleyebilmek ve Dean Hall'un oyun vizyonunu gerçekleştirebilmek için geliştirme sürecinin ortasında oyun motorunu ${ }^{16}$ (oyunun kod olarak altyapısını) değiştirme kararı almıştır. Bu sebeple 5 yıllık geliştirme süreci boyunca, oyuncular her dönemde biraz keyfine göre işleyen bir oyun programını oynamıştır. Oyunun tam sürümü yayınlanmış olmakla birlikte, geliştirme süreci güncellemelerle sürmektedir ve DayZ hala tam anlamıyla stabil sayılamayacak bir yazılımdır.

Oynanışın hem tasarım anlamında kasıtlı zorluğu, hem de yazılımın bu etkiyi artıran aksaklığı ve dengesizliği, bazı gündelik oyuncuları uzaklaştıııken, oyunsever (ludophile) başka bir kitleyi ise cezbedebilmektedir. Örneğin Youtube yayınCISI ve DayZ oyuncusu rhinoCRUNCH, DayZ oyun modunu "Kazara gerçekleşmiş epik şey"17 olarak ifade etmektedir (Rhinocrunch, 2017). Oyuncular oyunun türü doğrultusunda şekillenmiş içerik ve oyunda kabaca da olsa verilen öykü ile oynanışta ortaya çıkan anlamlar arasında ayrım gözetmektedir. Bu doğrultuda küçük detaylarla kendini gösteren zorlayıcılık, dengesizlik, kaza ve rastlantıların anlatıya etkisi oyunu zevkli kılan öğelerdir. Oyuncular bunları benimsemekte ve tasarlanmış (veya hatalı tasarlanmış) şeyler olarak değil kendi oynayışlarının ürünü olarak görmektedir.

Tasarımcı Hall'ün Arma 2 için ürettiği DayZ modunun karmaşık durumlara gebe olduğunu bilmediğini söyleyemeyiz. Dean Hall bir röportajda şöyle ifade ediyor:

15 Yazılım geliştirme sürecinde ürünün geldiği son duruma bağlı olarak pre-alpha, alpha, beta, release candidate gibi isimler alan aşamalar bulunmaktadır. Alpha aşamasında bir yazılım veya oyunun çok sayıda hata içermesi, oyunun bazı temel özelliklerinin hala eksik olması mümkündür.

16 Oyun motoru (game engine) oyunun görsel arayüzünün altında işleyen kod yapısıdır. Bir oyun motoru ile birden fazla oyun üretilebilmektedir. Sadece oyun motoru üreten firmalar bulunmaktadır. Geliştirici firmalar oyun motorlarını kendileri üretebilecekleri gibi, hazır olanları da kullanabilirler.

17 Yazar tarafından çevrilmiştir. 
Aslında zorlayıcı bir deneyim sunan şey dengesizliğin kendisi. Ben kasten ARMA oyununun gittiği yönü takip etmeyi ve bunu bir bağlama oturtarak insanlarda çeşitli duygular uyandırmak için ARMA'yı kullanmayı tercih ettim. Bir bakıma neredeyse bir "anti-oyun" (antigame) oldu, çünkü orada oturup "Tamam, bu silahın dengelenmesi lazım" veya "oyuncular bu şartlarda başlıyor, bunu şehirlere gittiklerinde dengelememiz lazım" şeklinde düşünmüyorsunuz ${ }^{18}$ (aktaran Lahti, 2012).

Hall, elbette oyun yazılımının hatalarını kastetmemektedir, ancak bir bakıma oyunun bir türlü bitirilemeyen, sürekli inşa halindeki yapısı ve bunun oynanışa etkisi kendi yaklaşımının dolaylı bir sonucu olarak görülebilir.

DayZ gibi, açık oyun dünyasına (open world) sahip, açık uçlu (open ended), kum havuzu (sandbox) olarak ifade edilen oyunlar, oyunculara gerekli araçları sunarak onları kendi oyunlarını kurmaya teşvik etmektedir. DayZ'nin geliştirme süreci, bu açıklığı biraz daha genişletmiş ve pek çok farklı öğeyi, oyun mekaniklerini ve bunların dengesini (ve dengesizliğini) tam anlamıyla kontrollü bir şekilde olmadan oyuna dahil etmiştir.

\section{DayZ'nin Oyun Dünyası: Chernarus}

Illk olarak ARMA 2'nin oyun dünyası olarak oyuncuların karşısına çıkan Chernarus, DayZ'nin Arma 2 üzerine kurulu bir mod olarak tasarlanmasıyla, bu oyunun da oyun dünyası olmuştur. Çek Cumhuriyeti'nin kuzeyindeki Děčín bölgesini kaynak almakla birlikte, şehir ve kasabaların adları Ukrayna'dandır. Chernarus'un tasarımında kullanılan yapıların önemli bir bölümü Rusya'daki çeşitli tarihi yapılardan örneklenmiştir (Smirnov, 2015). Bu karışım Chernarus'u Sovyet Sosyalist Cumhuriyetler Birliği'nin dağılmasının ardından herhangi bir Doğu Bloğu ülkesine atfedilebilecek bir soyutlama olarak kurmaktadır.

Chernarus'ta kurgusal bir iç savaşın izlerine rastlamak mümkündür. Chernarus Savunma Güçleri ile Sovyet yanlısı Chernarus Kızıl Yıldız Hareketi güçleri arasındaki iç savaşa Rusya, ABD ve Birleşmiş Milletler dahil olmuştur. Esas olarak ARMA 2'nin öyküsünden beslenen bu görünüm, DayZ'nin dünyasına aynı haritanın kullanılmasıyla dahil olmaktadır. DayZ'de ARMA 2'nin öyküsünden farkıı olarak, "zombi kıyameti" teması eklenmiştir. Bu felaket sonrasında zombilere karşı da savaşan bu askeri güçler salgını engelleyememiştir.

Bilgisayar oyunlarında yapılar genellikle dekor niteliğinde, cephe (façade) olarak temsil edilirken, Chernarus'da oynanabilir vaziyetteki iç tasarımları ile yer almaktadırlar. Gerek oyun dünyasının büyüklüğü (225 kilometrekare), gerekse içleri tamamen erişebilir olan binalar, oyuncular arasındaki silahlı çatışmaların taktik düzeyde niteliğini değiştirmekle kalmayıp, oyuncunun bu

18 Yazar tarafından çevrilmiştir. 
post-apokaliptik dünyanın bir parçası olarak hissetmesini, bu mekânlara kendi yerleşimlerini kurmasını sağlamaktadır.

Chernarus oyun dünyasının önemli bir parçası da oyunun konusundan kaynaklı olarak karşılaşmanın kaçınılmaz olduğu zombilerdir. Bir çiftlik dolaylarında yerel kıyafetler ile veya şehirde daha modern giysilerle, hastane yakınlarında doktor önlükleri, askeri bölgelerde ise üniforma içinde gezinip duran zombiler, Chernarus'un bir zamanlar var olan canlı halinin silinmeye başlamış izlerini taşımaktadır. Oyunda oyuncunun bulup giyebileceği çoğu kıyafet zombilerin de üstünde bulunabilmektedir.

Gerek erişilebilir iç ve dış mekânları ile oyun dünyası, gerekse giysi gibi nesneler oyuncuları oyun içinde rol yapma yönünde teşvik etmektedir. Mekâna yedirilmiş küçük öykü öğeleri oyuncular tarafından devralınmakta ve canlandırılmaktadır. Doktor, hemşire, gazeteci, itfaiyeci veya polis kıyafetleri içinde, bunlara uygun nesneleri toplamış ve oyun dünyasında bulundukları mekânı buna uygun seçmiş oyunculara rastlamak mümkündür. Tasarımdan kaynaklanan veya kazara ortaya çıkan yaralanma, kaybolma gibi durumlarda oyuncular buna uygun olarak rol yapabilmektedir.

Pek çok oyunun görsel arayüzünde ${ }^{19}$ oyuncunun oyun dünyasının neresinde olduğunu gösteren küçük bir harita bulunmaktadır. DayZ oyununda bu haritanın olmaması, oyun dünyasının büyüklüğü ve yerleşim yerlerinin oyun içindeki tabelalarının Kiril alfabesi ile yazması kaybolmayı oyun deneyiminin önemli bir parçası haline getirmektedir. Kaybolmanın neticesinde aç ve susuz kalmak, yaralanmak ve tehlike hissi yerleşim yerlerinin oyun açısından anlamını derinleştirmekte, diğer oyuncularla karşılaşmaları ise beklenmedik ve sarsıcı bir hâle getirmektedir.

Şehirlerden ve askeri bölgelerden uzak yerlerde, oyuncular kimi durumlarda kamp yapmakta veya takım hâlinde yerleşimler kurmaktadır. Bu kamplar diğer oyuncuların yağmalaması için cazibe merkezleri olduğundan, oyun mekânı dinamik bir yapıya bürünmektedir. Tıpkı geliştirme sürecinden kaynaklı olarak oyuncuların tasarımda sözü olması veya oyunun küçük detaylarını sahiplenmesi gibi, tasarlanmış oyun dünyasını da kendi çabalarının bir ürünü olarak duyumsayabilmektedirler.

\section{DayZ'nin Teknolojik Altyapısı}

DayZ oyunu, Take On Helicopters'de (Bohemia Interactive, 2011) kullanılan Real Virtuality oyun motoru ile yola çıkmıştır. Ancak geliştirme süreci içinde Enfusion isimli yeni bir motora geçilmiştir. Enfusion'ın DayZ'ye eklenen en

19 Arayüz (interface) terimi yazılım ile kullanıcı arasındaki etkileşimi sağlayan görsel, işitsel mekanik araç ve sistemler için kullanılmaktadır. Oyun ile oyuncu arasında etkileşimi sağlayan görsel katmana ise görsel arayüz (Graphical User Interface) denmektedir. Oyun çubuğu, fare veya klavye gibi mekanik araçlar söz konusu olduğunda ise genelde arabirim terimi kullanılmaktadır. 
önemli parçası ise yeni bir görüntü işleyicidir ${ }^{20}$ ve bu geliştirme görsel gerçekçilik açısından aslına daha sadık bir simülasyon ortamı sağlamaktadır.

Bohemia Interactive'in geliştirdiği oyun motorlarının oynanış üzerindeki etkisi geniş oyun dünyalarında, farklı hava durumu şartlarında, gece-gündüz döngüsü içerecek şekilde, çok sayıda oyuncuya oynama imkânı sunmasıdır. Bu geniş oyun dünyalarının içinde kara, hava ve deniz araçlarının kullanılması da mümkün kılınmıştır. DayZ, bu altyapı üzerine oyuncuların kendi binalarını inşa etmesi ve bu yapılar için gerekli malzemeyi üretmesi imkânını da eklemiştir.

Gece-gündüz döngüsü oyun dünyasının aydınlatmasının değiştirilerek zamanın akışının simüle edilmesidir. Bu durum gerek oynanış gerekse oyuncunun mekânı duyumsaması üzerinde etki göstermektedir. Oyuncular gece olduğunda çeşitli ışık kaynaklarına ihtiyaç duymaktadır. Diğer oyuncuların bunu görme ihtimali oynanışı doğrudan belirlemektedir. Karanlıkta kalmayı tercih etmek zombilerin saldırılarını daha tehlikeli hale getirmektedir. Açlık mekaniği ateş yakmayı zorunlu kılmaktadır ve geceleyin bu da tehlike yaratmaktadır. Oyun mekanikleri oyunun kurallarının nasıl tasarlandığı ve oyunun nasıl kodlandığı ile ilgili olmakla birlikte, ortaya çıkan olasılık ufku tasarımcının tam anlamıyla kontrolünde değildir. Farklı oyun mekaniklerinin, oyuncu tercihleri sonucunda ortaya çıkan durumların karmaşık ilişkisi oyunun anlatısını kuran unsurlardandır.

\section{DayZ'nin Asgari Öyküsü}

DayZ'nin öyküsü oyun dünyasının tasarımına yedirilmiş olarak yer almaktadır. Bu yaklaşım, çevresel öykü anlatıcılığı (environmental storytelling) olarak adlandırılmaktadır. Zombi kıyameti ve doğu bloğu ülkesinde ABD-Rusya vekil savaşı temalarının bir kombinasyonu DayZ'ye bir bağlam sağlamaktadır. Oyuncunun takip edebileceği hazır görevler ${ }^{21}$ (mission, quest), bu görevlerin metinleri veya görevleri verecek oyun karakterleri22 (NPC: Non-player Character) yoktur. Hayatta kalmak yegâne amaç23 (goal) olarak gözükmektedir. Oyuna dahil edilen

20 Görüntü işleyici (renderer) matematiksel bir model olarak oyun dünyasının, nesne ve karakterlerin bilgisini alarak görsel gerçekçilik sunan grafiklere dönüştürmekten sorumludur. Farklı üç boyutlu modeller farklı açılardaki güncel halleriyle alınarak, ışıklandırmaya ve perspektife bağlı olarak sentezlenmektedir. Gölgeler, dokular, alan derinliği, ışık kırılma ve yansımaları gibi pek çok görsel öğe görüntü işleyici ile sahneye katılmaktadır.

21 Görevler (mission, quest), oyunlarda oyuncuları yönlendiren, hedefler sunan, sayısallaştırılması ve denetlenmesi mümkün öykü parçalarıdır. Görevler oyun sanal karakterler tarafından veya doğrudan oyun arayüzü aracılığıyla verilebilmektedir. Örneğin, oyuncudan 10 adet odun bulması veya bir başka karakterle konuşması istenebilir. Görev tamamlandığında hem öykü başka bir aşamaya ilerler, hem de oyuncu oyun içindeki değerli materyaller ve deneyim puanı ile ödüllendirilebilir.

22 Oyun karakterleri (NPC: Non-player character) bilgisayar kontrolünde, oyuncuların yönetmediği karakterlerdir. Programlandıkları şekilde oyuncuyla diyaloğa geçip görevler verebilir, oyun dünyasında farkı noktalarda bulunup gezinebilirler. Rol yapmanın ağırlıkta olduğu RPG (Role-Playing Games) oyunlarında karakterler gece-gündüz döngüsüne bağlı olarak gündüz bir mekânda çalışıp gece evlerine dönebilirler.

23 Amaçlar veya hedefler (goals) oyunu kazanmak için yapılması gereken eylemlerdir. Örneğin, futbolda topun rakip çizgisini geçmesi gerekmektedir. Satrançta rakibin şahını yenileceği pozisyona 
sağlık durumu, kan kaybı, beslenme ve hastalıklardan kaynaklı intiyaçlar oyuncuyu bunların giderilmesi noktasında kendi alt hedeflerini (sub-goals) ${ }^{24}$ koymaya itmektedir. Farklı oyuncularla gelişen ilişkiler, bireysel intiyaçların yanına sosyal gereksinimleri de yerleştirmektedir. Bu hedefleri kovalamakla geçen sürecin kabaca bir öykülemesini yapmak elimizdedir.

Oyuncular oyuna Chernarus'un kıyı bölgesinde, üzerlerinde basit kıyafetler ve bandaj olarak kullanılabilecek bir bez parçası gibi ekipmanlarla başlamaktadır. Oyuncunun yönelebileceği en akla yatkın seçenek intiyaç duyduğu malzemeleri ivedilikle temin etmek olacaktır. Bu da elbette diğer oyuncularla karşılaşma riskini artıracaktır.

Karşılaşmalarda oyuncuların birbirlerine sesli konuşma imkânını kullanarak "Friendly!" (Dostum, düşman değilim!) şeklinde seslenmesi adet haline gelmiştir. Ancak taraflardan biri diğerine karşılık vermeyebilir veya bazen iki taraf da konuşmamayı tercih edebilir. Diyaloğun yokluğu tehlike işareti olarak yorumlanmaktadır. Diyaloğa geçildiği noktada, ihtiyaçlar, oyuncunun nereden gelip nereye gitmekte olduğu ve benzeri konular üzerine konuşulabilmektedir. Bazen eldeki silahların karşııklı olarak kaldıııması da talep edilebilir. Güven sağlandığı durumlarda oyuncular ekip olarak davranmayı tercih edebilmektedir. Öte yandan bazı durumlarda oyunculardan biri diğerini ihanet ederek öldürebilmektedir. Bu ve benzeri öğeler oyunun tümüne tedirginlik duygusunu egemen kılmaktadır.

Kıyı kesiminin uzağındaki askeri bölgeler, oyuncu karşılaşmalarının daha düşmanca olabildiği yerlerdir. Karşılaşmalar bir tarafın veya iki tarafın birden ölümüyle sonuçlanabilmektedir. Oyuncular takım arkadaşlarıyla bu bölgeye geldiyse sağ kalma şansları daha yüksektir. Takım arkadaşı öldürülürse, her şeyini kaybederek kıyı kesiminde yeniden oyuna başlayacaktır. Takım arkadaşı oyun içinde yeni tanışılan bir oyuncuysa oyun dünyasının büyüklüğünden ötürü bir daha karşılaşma intimali oldukça düşüktür.

Oyuncunun eylemleri sonunda geliş̧tirdiği ilişkiler ve karşılaşmaların dinamikleri; kayıp, ölüm, ihanet gibi temaları DayZ anlatısına dahil etmektedir. Ciddi konuların, negatif duyguların bilgisayar oyunlarında öyküye dahil olması yeni bir olgu değildir, ancak DayZ oynanışın kendisi ve oyun dünyasındaki minimal öğelerle oyuncu üzerindeki etkiyi özel bir şekilde kurmakta, oyuncuya bu duyguları kimi zaman oldukça sarsıcı bir şekilde yaşatmaktadır. DayZ anlatısının can alıcı yönlerini oyunda görsel ve metinlerle verilen öyküde değil oynanışta aramak gerekmektedir.

24 Alt hedefler veya amaçlar (sub-goals), ana hedefin dışındakilerdir. Oyun sistemi oyuncuya alt-hedefler sunabileceği gibi oyuncunun oyun dünyasında keyfince belirlediği alt hedefler de olabilir. Örneğin, oyun sistemi tarafından belirtilmese veya ödüllendirilmese de bir oyuncu oyundaki en yüksek tepenin zirvesine çıkmayı kendine amaç edinebilir. 


\section{DayZ'de Oynanış}

DayZ, oynanış (gameplay) olarak incelendiğinde dört temel nokta göze çarpmaktadır: Kurallar bağlamında hayatta kalma oyunlarına ait özellikler, oyunun amaç olarak koyduğu hayatta kalma durumu ve tersi olan ölümün nasıl oyunun temsil sistemine dahil edildiği, oyuncular arası ilişkileri belirleyen PvP mekaniğinin özgün biçimi ve konum bazlı sesli konuşma imkânı. Temelde bu dört özellik ve bazı diğer yan unsurlar özgün bir anlatı yapısının ortaya çıkmasını sağlamaktadır.

DayZ'nin hayatta kalma oyunları ile paylaştığı ve öyküyle ilişkili olarak ele aldığımız sağlık durumu mekaniği çeşitli değişkenler içermektedir: Sağlık değeri, kan değeri, kemik sağlığı, travma, vücut sıcaklığı, hastalık durumu, mide kapasitesi ve doluluğu vb. Bu detaylı yapı ve pek çok nedenle oluşabilecek hastalıklar (kolera, salmonella, grip, hipotermi vb.) oyun karakterinin oldukça kırılgan bir varlık olarak duyumsanmasını sağlamaktadır. Kan kaybı, yüksekten düşmek, darbe almak, kurşun yarası, hayati organlardan vurulmak, aşırı sıcak, aşırı soğuk, kirli su içmek, çiğ veya zehirli yiyecekler yemek, açlık veya aşırı yemek gibi nedenlerle karakterin sağığını yitirmesi mümkündür. Dolayısıyla oynanışın başat unsuru oyun karakterini sağlıklı tutmak, hayatta kalmasını sağlamaktır.

Hayatta kalma oyunlarının pek çoğu tek kişilik veya PvE (Player versus Environment) olarak ifade edilen, oyuncunun gerçek başka oyunculara karşı değil, onlarla birlikte bilgisayar kontrolündeki karakterlere karşı oynadığı oyunlardır. DayZ'de ise önemli bir fark kitlesel çevrimiçi bir oyun olması ve PvP'nin kısıtlanmamış olmasıdır: Oyuncuların birbirlerine saldırmaları, yaralamaları veya öldürmelerini engelleyen hiçbir teknik, zaman veya mekân sınırlaması bulunmamaktadır. Dolayısıyla dolu bir DayZ sunucusunda bulunan 60'a yakın oyuncu hem hayatta kalmak için olumsuz şartlarla mücadele etmek hem de diğer oyuncularla ilişkilerinde hayatta kalabilecekleri doğru seçimler yapmak zorundadır. Oyunun PvP özelliğine dikkat çeken Backe ve Aarseth'e (2013, s.12) göre:

Uyulacak kurallar olmadığında, oyuncuları karşı karşıya getiren dinamik sınırlı kaynaklar yüzünden ihanete ve soğuk kanlı cinayetlere neden oluyor. Bu basit sosyal dinamikle oyun, insan doğasının karanlık yönlerine dair hiçbir korku oyununun rekabet edemeyeceği, Kirkman'ın The Walking Dead'ini andıran bir ders veriyor. ${ }^{25}$

DayZ'yi farklı kılan temel oynanış unsurlarından biri de kalıcı ölüm (permanent death veya perma-death) içermesidir. Kalıcı ölüm mekaniğine sahip oyunlarda, oyuncunun yönettiği karakter öldügünde her şeye sıfırdan başlanmaktadır. Oyuncu kaldığı yeri kaydedip yükleyemez, yakınlarda bir yerde yeniden doğamaz, aynı karaktere sahip olamaz ve sahip olduğu materyalleri tamamen kaybeder. Sanal oyun nesnelerinin saklanıp geri alınabileceği, bir komutla veya belirli bir konumda erişilebilen, yeni karaktere miras bırakılabilecek bir sanal kasa (vault, bank, permanent inventory) da bulunmamaktadır. Oyuna dahil olan, oyuncunun bulup 25 Yazar tarafından çevrilmiştir. 
kullanabileceği çadır, kasa veya varil gibi saklama ortamları yağmalanmaya açıktır ve çoğunlukla diğer oyuncular tarafından kolayca bulunmaktadır.

Stratejiye dayalı, çok sayıda karakterin yönlendirildiği, oyuncunun belli bir karakterin kaybından dolayı oyunu kaybetmediği bir oyunda kalıcı ölüm aynı derecede etkili olmamaktadır. Örneğin, XCOM 2 (Fraxis Games, 2016) oyunu ve benzeri taktiksel veya stratejik oyunlar Ironman ${ }^{26}$ modunda oynandığında, oyunu kaydedip aynı görevi yeniden oynamak mümkün değildir ve bu yüzden çeşitli görevlerde kaybedilen karakterler oyun dışında kalırlar. Ancak bu durum bu karakterleri yöneten general rolündeki oyuncunun ölümünü veya oyuna yeniden başlamasını beraberinde getirmez. Kalıcı ölüm gerçek anlamını oyuncu yönettiği karakterin kaybını oynanış olarak oyuna verdiği emek ve zamanın mutlak kaybı olarak yaşadığı, bununla özdeşleştiği ölçüde kazanmaktadır. Kalıcı ölümün hayatta kalma oyunu mekanikleri ve sınırlandırılmamış PvP sistemi ile birlikte sunulması DayZ'nin öncülük ettiği bir kombinasyondur.

Konum bazılı sesli konuşma imkânı, DayZ'nin oynanışına etki eden bir diğer önemli unsurdur. Bu sistem oyuncuların birbirlerini ancak belli bir yakınlıktayken duyabilecekleri niteliktedir. Ayrıca bir oyuncu konuştuğunda, belli bir uzaklıktaki dost veya düşman herkes konuşmasını dinleyebilmektedir. Bu durum gerek birlikte takım oluşturmuş oyuncular, gerekse onlarla çatışma içindeki diğer oyuncular için daha gerçekçi bir deneyim sağlamaktadır. Seslenmek, fısıldamak, bazen de düşmanla siperden sipere konuşup pazarlık etmek mümkün olmaktadır. Çift kanallı (stereo) ses sayesinde konuşan oyuncunun konumunu anlayabilmek de mümkündür. Bu durum mekânın duyumsanışını da güçlendirmektedir.

Sesli konuşma imkânı, ikinci bir mekanikle oyuna yine dikkat çekici başka bir özellik kazandırmıştır. Oyuncular oyunda buldukları telsizlerle farklı kanalları deneyerek telsizi olan başka oyunculara ulaşmaya çalışabilmektedirler. Eğer sunucuda o anda aynı kanala ayarlanmış açık bir telsize sahip olan başka bir oyuncu varsa, yayını duyacaktır. Telsiz mekaniği oyuncuların buluşup takım olmaları kadar birinin diğerine tuzak kurmasını da sağlayabilmektedir. Daha güçlü telsizler kullanılarak oyun içinde radyo yayıncılığı da yapılabilmektedir.

Ana unsurları besleyen tali unsurlar da bulunmaktadır. Bunlardan ilki kitlesel çevrimiçi oyunlarda bulunan seviye atlama, karakter geliştirme, nesne biriktirme özelliklerinin yokluğudur. Dayz'de karakterin sağlık durumunun iyi olması ve bazı temel materyallere sahip olması dışında geliştirilebilecek başka bir özellik bulunmamaktadır. Örneğin balık tutmak konusunda seviye atlayarak daha fazla balık tutulması mümkün değildir veya daha fazla silah kullanmak karakterinizi daha

26 Demir adam (Ironman) seçeneği, oyunun güncel halinin, yani oyun durumunun kaydedildiği dosyanın oyuncunun hata yapma durumlarında geri yüklenmesini, yani kaydet-geri yükle taktiğini (save/load, MS Word dokümanında Geri Al komutu vermeye de benzetilebilir) engelleyen bir özelliktir. Yönetilen kaynaklar, karakterler kaybedildiğinde, görevlerde hatalar yapıldığında bir anlamda zamanda geri dönüp aynı görevi sıfırdan başlayarak oynama imkânı bulunmamaktadır. Oyun durumu ancak oyundan çıkılığı anlarda devam etmenin mümkün olabilmesi için kaydedilir. 
isabetli atışlar yapacak şekilde geliştirmez. Bu durum kitlesel çevrimiçi oyunların seviye atlamayı sağlayacak eylemleri sürekli tekrarlamaya dayalı oynanışının (grinding ${ }^{27}$ dışında bir olasılığın da olduğunu göstermektedir. DayZ'de oynanış, oyun zamanının (play-time) ${ }^{28}$ materyal kazanımlara dönüştürülmesi, bu kazanımların sermaye birikimi gibi işlev görmesi, oyun nesneleri piyasası ve bu piyasadaki mübadele ilişkileri gibi kitlesel çevrimiçi oyunların güncel örneklerinde bulunan bazı özellikleri içermemektedir. Bunun yerine ölümün tek mutlak olduğu ve birikimin değersiz kılındığı, "kefenin cebi yok" diyen bir dünya sunmaktadır.

Yeni bir DayZ oyuncusu başka oyunlardan getirdiği alışkanlıklarla sahip olduğu nesnelere sımsıkı sarılacaktır. Bu durum gereksiz olmanın ötesinde oyuncuyu engelleyecek, oyununu olumsuz olarak etkileyecek şeylere de sebep olabilir. Örneğin, sırt çantasında acil bir şekilde aradığı bandajı görememek gibi.

Village sunucusunda oynayan Brad, ekipman seçimini şöyle açıklıyor:

Eskiden hep en iyi ekipmanı kovalardım. Daha uzun süre hayatta kalabilmek için çatışmada bana üstünlük sağlayacak askeri teçhizatları alırdım. Fakat daha sonra fark ettim ki üstümde daha değerli ekipmanlar oldukça, risk alıp harekete geçmem gereken yerlerde risk almamaya başlıyorum. Tutucu davrandığımdan köşeye sıkıştırılıp vuruluyorum. Bugünlerde orta derecede ekipmanları tercih ediyorum. Böylece zor bir pozisyona girdiğimde kafamda kaybedecek bir şeyim olmadığı düşüncesi oluyor ${ }^{29}$ (Kişisel görüşme, 12 Eylül 2019).

Diğer oyuncuları avlamaya yönelen oyuncular açısından büyük bir sırt çantasına sahip birini görmek, o oyuncuyu öldürüp eşyalarını almayı daha cazip kılmaktadır. Usta oyuncular bu ve benzeri etkenleri dikkate alarak sadeliği tercih etmektedirler.

İkinci tali unsur DayZ'nin oyun arayüzünü kullanma biçimidir. Oyunun ve karakterin durumu ile ilgili bilgiler alternatif ve oldukça minimalist bir biçimde sunulmaktadır. Örneğin sağlık durumu görüntünün bulanıklaşması, kan kaybı ise renk kaybederek siyah-beyaza kayması şeklinde bildirilmektedir. Ekran üzerinde oldukça sınırlı sayıda gösterge bulunmaktadır. Bu durum, oyuncuda oyunun gerçekçiliği duygusunu artırmak için kullanıımıştır.

Kalıcı ölümün görsel temsili için tasarlanan ekranlar da farklılık göstermektedir. DayZ'de bayılma durumlarında ekran tamamen siyaha dönmektedir. Bu esnada oyuncunun çeşitli ilk yardım yöntemleri ile hayata döndürülmesi mümkündür. Ayrıca oyuncu bazı durumlarda kendiliğinden ayılabilmektedir. Oyuncu bayıldığında

27 Tekrarlamaya dayalı oynanış (grinding), tekrarlı olarak pek yaratıcıık içermeyen bir eylemin yapılması olarak oyuncu kültüründe yer etmiştir. Örneğin, bir oyun, karakterin seviye atlayabilmesi için saatlerce farenin bir tuşuna tıklayarak maden kazmayı gerektiriyor olabilir. Bu oyun biçimi bir anlamda oyuncunun sabrını aşındıracak niteliktedir.

28 Oyun zamanı, oyun içinde geçirilen gerçek süredir. Belirli bir oyun eyleminin gerçek süre olarak karşıı̆ı olarak da ele alınabilir. Örneğin bir oyunda bir binanın inşası 2 saatte bitebilir. Öte yandan oyunun kurgusal katmanında bu süre, öykü zamanı ile 2 yıl geçmiş olarak verilebilir.

29 Yazar tarafından çevrilmiştir. 
kurtarılamazsa ekranda sade bir şekilde "Öldün" yazısı belirmektedir. Oyunun bütün aksiyonu ve fotogerçekçi grafikleri karşısında bu temsil oldukça donuk, çaresiz ve değersizleştirici bir izlenim sunmaktadır. Bayılma anı ile "öldün" mesajının belirmesi arasındaki bekleyiş ise gerilim yaratmaktadır. DayZ arayüzü bu ve benzeri duyguları ortaya çıkarmak için basit ama etkili yöntemler sunmaktadır.

Oyun dünyasının tasarımı ve görsel gerçekçiliği saydığımız diğer unsurları destekleyecek şekildedir. Göz alııı manzaralar oyuncuyu oyun dünyasına dahil ederken aslında dinginlik verecek niteliktedir. Oyun dünyasının büyüklüğü oyuncunun uzun süreler oldukça olaysız bir şekilde gezinebilmesine neden olmaktadır. DayZ tasarımcısı Hall bunu şu sözlerle ifade etmektedir:

Kafada onca gerilim varken, komik olan şu ki, insanlar bir saat gezinebilir ve hiçbir şey olmayabilir. Yine de kalpleri çarpmakta, adrenalin yükselmektedir, çünkü neler olup bittiğini bilmiyorlardır ${ }^{30}$ (aktaran Lahti, 2012).

Oynanış açısından, bu oldukça eylemsiz ekipman veya yiyecek arama anları ile çatışma anları arasındaki zıtıı duygusal etkiyi de güçlendirmektedir. Dramatik yapı oynanışla iç içe geçmiş vaziyettedir. Burada sayılan özellikler dahilinde, DayZ durmaksızın çalışan bir öykü üretme makinesi olarak işlev görmektedir.

\section{Oynanış ve Anlatı İlişkisinin Üç Katmanı}

DayZ'nin anlatısı üç farklı katmanda işlemektedir: Oyun öyküsü, prosedürel olarak oluşan ifadeler ve ihlalci oyunla ${ }^{31}$ (Aarseth, 2007) oluşan hataların sonucu üretilen anlamlar. Bu doğrultuda, örnek olarak oyundaki karşılaşmalar ve olasıııklar üç farklı katmanda ele alınacaktır.

Birinci düzey oyunun öyküsünde yer alan olasılıklardır. İki karakterin karşılaşması, bir karakterin merdivenden düşmesi ve yaralanması veya bir nesne bulması oyun öyküsünün gereği olarak gerçekleşebilir. Bu ilk düzeyde oyunun öyküsü oyuncuya bir olayı şans eseri gerçekleşmiş gibi anlatır, ancak aslında tasarımdan kaynaklı olarak her oyuncu için gerçekleşmektedir. Olayların birbirini çizgisel olarak takip ettiği, olay örgüsünün çatallanarak farklı sonuçlara gitmediği oyunlarda bu birinci düzeydeki rastlantılar geçerlidir.

İkinci düzeyde, oynanış esnasında bazı unsurlara rastlamak olasılığa tabi kııınmıştır. Rastlantılar tasarımcılar tarafından önceden planlanmıştır. Nesneler

30 Yazar tarafından çevrilmiştir.

31 İhlalci oyun (transgressive play), oyuncunun oyunu oyun sisteminin yönlendirdiği şekilde değil, tam da oyun sistemine karşı oynadığı bir oyun biçimidir: Gidilmesi normalde mümkün olmayan yerlere gitmek, oyun dünyasının sınırlarının dışına çıkmak, karakterlerle yapılması mümkün olmayan diyaloglara girmek, bir görevi oyun sisteminde kodlanmamış bir şekilde çözmek, oyunda yer almayan bir nesneyi çeşitli tekniklerle oyun içinde üretip sahip olmak vb. Oyunların program olarak yapıları oldukça karmaşık olduğundan, bazı durumlarda farklı algoritmaların birbirlerine karşı kullanılması ile, önceden planlanmamış sonuçlar elde etmek mümkün olabilmektedir. 
oyun dünyasına prosedürel olarak serpiştirilmiş, kaza olasılıkları belirlenmiş, karakterler karşılaşabilecekleri yerlere gevşekçe de olsa yönlendirilmiş olabilir. Oyuncu açısından buna benzer olasılıkların gerçekleşmesi diğerlerine göre daha anlamlı ve özel gelecektir.

Üçüncü düzey ise hata olarak ortaya çıkan olaylardır: Tasarımcının öngörmediği şekilde iki karakter oyun sistemine göre imkânsız bir yerde karşılaşır, bir karakter oyun kodundaki hatadan dolayı merdivenden düşer veya yolda oyundan çıkarıldığı zannedilen bir nesne bulur. Bu gibi durumlar glitch olarak adlandırılan oyun kodundaki hatalardan kaynaklanabilmektedir. Oyun yazııımının bir eksikliği oyun dünyasında oyunculara etki edecek şekilde vücut bulmakta, dolayısıyla da oyunun anlatısına katılmaktadır (Holmes, 2010). Oyuncunun oyundaki sonsuz olasılık taşıyan eylemlerinin ürettiği bir kaza olarak gerçekleşebileceği gibi, oyuncunun kendi isteğiyle sürdürdügü ihlalci oyununun (Aarseth, 2007) neden olduğu, öngörülememiş bir eksiklik de olabilir.

DayZ oyunu birkaç farklı nedenden dolayı bu üçüncü tarz olasılıklara da gebedir. Oyunun ARMA 2 modu olarak başladığı hayatı ve buradaki uyumsuzluklar, denenen eski oyun motoru ve tasarlanan oynanışın bu motora uymayışı, geliştirme sürecindeki kesintiler, oyunun daha alpha aşamasında erken erişime açılması ve yıllarca bu durumda kalması, pek çok oyun mekaniğinden önce oyun dünyası ve nesnelerinin oyuna dahil edilmiş olması, tasarımcısı Hall'ün deneysel yaklaşımı gibi nedenler sayılabilir.

Bu hatalar DayZ'de içine girilmesi mümkün olmayan sınırlı sayıda mekâna da eşya saklanmasını veya kamp kurulmasını sağlamıştır. Oyuncular oyun içindeki araçları, oyun dünyasının sınııının ötesindeki tasarlanmamış bölgeden daha kolay sürebilmektedir. Bir nesnenin çeşitli yöntemlerle sonsuz kopyasını üretmek mümkün olmuştur. Bu yöntemler hile yapmak (cheating) olarak nitelendirilebilir. Öte yandan bazı hatalar oyuncular tarafından sanki oyunun kendi ürettiği ifadelermiş gibi okunabilmektedir. Oyunun geliştirme sürecinin erken bir evresinde oyuncular merdivenlerden çıkarken yazılımdaki bir hatadan dolayı, tasarımcının arzusu dışında düşebilmekteydi. Bu durum oyuncular tarafından, aslında hayatta da başa gelebilecek bir olay olarak, oyunun büyüsünü bozmayan, kendi öykülerinin bir parçası olarak anlamlandııımaktadır.

Üzerinde durduğumuz oynanış ve anlatı öğeleri, bir başka oyun örneği olarak Minecraft'ın (Mojang, 2009) da oyuncuları tarafından sahiplenilmesinde ve beklenenin çok üstünde bir ilgi görmesinde etkili olmuştur. Minecraft'ın Lego parçalarına benzer çocuksu dünyasının deneysel açık uçlu ortamı yaratıcılığı körüklerken, DayZ'nin yetişkinlere daha uygun teması anlatım açısından daha karmaşık ifadeler üretebilmektedir. 


\section{DayZ ve Oyuncu Rolleri}

DayZ sunucularında oyuncu sayısı kısıtlaması olduğundan oyuncular farkı sunuculara dağılmış olarak bulunmaktadır. Resmi sunucular yanında farklı toplulukların kendi özel sunucuları da bulunmaktadır. Topluluk sunucuları oyun deneyimi açısından daha iyi sonuçlar vermekte, müdavim oyuncuların arasında kalıcı ilişkilerin gelişmesine olanak tanımakta, farklı temalar, deneysel girişimler daha rahat gerçekleştirilmektedir. Örneğin, bir topluluk sunucusu tamamen rol yapma (RP: roleplay) üzerine uzmanlaşmış olabilmektedir. Böyle bir sunucuda oyuncular oyunda sanki zombi kıyametinde hayatta kalmış insanlar gibi rol yapmak zorundadır, aksi durumlar kurallara aykırı olduğundan geçici veya kalıcı olarak sunucudan men edilmeyle (banning) ${ }^{32}$ sonuçlanabilmektedir.

DayZ sunucularındaki oyuncu etkileşimlerinde kendiliğinden ortaya çıkmış ve oyuncu kültüründe yer etmiş bazı roller bulunmaktadır. Bunlar oyun sisteminin teknik olarak sunduğu, oyunun koduna entegre kimlikler değil, tamamen oyuncuların rol yapma biçimleri, tercihlerinin bir sınıflaması olarak şekillenmiştir. Bunlardan ilki olan survivor tipi (hayatta kalan, kurtulan) çoğunlukla oyuna yeni bağlanmış (fresh spawn) oyuncuların tümü için kullanılmakla birlikte, belli davranış veya rol yapma kalıplarına sahiptir. Bu tipte bir oyuncu çoğunlukla fazla bir malzemeye sahip değildir ve yardıma intiyacı vardır. Nedensiz saldırması beklenmez, amacı hayatta kalmaktır. Balık tutmayı, şehir ve kasabalardan yemek toplamayı, çiftçilik yapmayı veya yaban hayatta avlanmayı tercih edebilir. Oyunda oyuncular sürekli ölüp yeniden doğduğundan her tipte oyuncu, oyun içindeki yaşamının başında bir süre bu rolde olacaktır.

Sık rastlanan başka bir tür rol de haydutlardır (bandit). Bu oyuncular hırsızlık, adam kaçırma, psikolojik işkence gibi şeyleri rol gereği yapmaktadır. Bir anlamda olumsuz eylemleri ile oyun dünyasındaki zombiler dışındaki kötü karakter boşluğunu doldurarak oyuna denge getirmekte ve oyunu zevkli kılmaktadırlar. Diğer oyuncular haydutlardan nefret eder gibi rol yapsa da oyun dışındaki mecralarda oyuna bir şeyler katmakta olduklarını kabul ederler. Haydutlarsa diğer oyuncuları sinirlendirmekten, sınırlarını zorlamaktan keyif almaktadır.

Üçüncü bir oyuncu türü kahraman (hero) tipidir. Bu tipte oyuncular koşullar ne olursa olsun diğer hayatta kalanlara yardım etmeye gönüllüdür. Bazen intiyaçlarını gidererek bazen de haydutlara karşı savaşarak hayatta kalanları savunurlar.

Oyun içindeki roller bu üç role sıkıştııılamaz, ayrıca bu roller kesin sınırlara da sahip değildir. Ancak burada bahsedilen roller, DayZ oyuncu kültüründe bu isimlendirmelerle kendiliğinden ortaya çıkmıştır. Bunun sonucunda, gerek bu roller sahiplenildiğinde, gerekse bu rollere uyan biriyle karşılaşıldığında neler olabileceğine veya

32 Banning (yasaklama, men etme, oyuncu jargonunda "ban yemek"), bir oyuncunun kural dışı davranması neticesinde oyun sunucusundan atılmasıdır. Süreli olarak veya kalıcı olarak gerçekleşebilmektedir. Geri dönmenin serbest olduğu anlık atılmalara ise kick (tekmeyi basmak) denilmektedir. 
neler yapılabileceğine dair oyuncuların kabaca da olsa bir fikirleri vardır.

Bunun dışında DayZ topluluğunun özellikle sevmediği bir kategori daha bulunmaktadır. KOS (Kill on Sight) olarak adlandırılan oynama biçimini sahiplenen oyuncular, yani diğer oyuncuları hiçbir diyalog, neden, oyuna anlam ve zevk katacak davranış olmadan görür görmez öldürenler haydutlardan ayrı tutulmaktadır. Haydutluk, sonucu yakalanmış oyuncunun ölümü de olsa öykü anlamında bir zenginlik katmakta, haydutun rol yeteneğine bağlı olarak kimi zaman büyük keyif vermektedir. Haydutun yakaladığı kişi kendini tiyatro sahnesinde zor bir sahnedeki oyuncu gibi duyumsar, doğaçlama ve yaratıcı bir ortaklaşa faaliyet söz konusudur. Karşılaşır karşılaşmaz ilk eylemin ateş açmak olduğu KOS ise bu imkânı ortadan kaldırdığından DayZ'nin ruhuna aykırı olduğu düşünülmektedir.

Oyuncu kültüründe yer etmiş bu roller ile oyuncu motivasyonları (Bartle, 1996; Yee, 2008) arasında birebir örtüşen bir ilişki kurmak mümkün değildir. Örneğin çok farklı motivasyonlara sahip oyuncular survivor rolünde bulunabilirler. Kahraman rolündekiler iletişim ve sosyalleşmeye daha yatkın görünmektedir, ancak diğer motivasyonlar açısından farklı eğilimleri olabilir. Haydutlar, diğer oyunculara karşı gelecek şekilde davranmaktadır, ancak bu davranışları grup halinde veya tek başlarına gösterebilirler. Rol yapma konusunda derinleşebilir veya daha yüzeysel olarak rol yapabilirler. KOS oyun biçimini sahiplenenler düşmanlarına karşı iletişim kurmazken, dostlarıyla ilişkileri farklı olabilir. Bütün bu rollerdeki oyuncular oyundaki nesnelerle maddi gereksinimleri doğrultusunda farklı düzeyde etkileşimler geliştirebilirler. Bu durum oyunda oyuncuların farklı motivasyonları olmadığını göstermemekle birlikte, DayZ oyuncu kültüründe yer alan roller ile oyuncu motivasyonları arasında birebir örtüşen bir ilişki olmadığına işaret etmektedir. DayZ oyununda oyuncu motivasyonları ile ilgili analizlere intiyaç olmakla birlikte, bu konudaki derinlikli bir tartışma bu çalışmanın kapsamı dışında kalmaktadır.

\section{Village Topluluğu}

Oyuncuların çevrimiçi oyunlardaki aktivitesi oyunun sınıları içinde kalmamaktadır. Oyuncular topluluklar olarak bir araya gelmekte, oyuncu topluluklarının da kendi tarihleri olmaktadır. Topluluklar arası ilişkilerin dinamik yapısı oyunun bir parçası haline gelmektedir. DayZ oyunu, bu toplulukların varlığı ve farklı mecraları kullanma biçimleri ile medyalar arası (transmedia) oynanan bir oyuna dönüşmüştür. Bu bölümde Village topluluğu ve kültürel üretimleri örnek olarak ele alınacaktır.

Village sunucusu 1 Eylül 2017 tarihinde, başka bir sunucuda başlayan bir deneyden sonra kurulmuştur: Oyuncular bir araya gelerek bir köy kurarlar ve burada yaşayarak zombi istilasında sağ kalan diğer insanlara yardım ederler. Projeye geniş katıım sağlanması ve popüler olmasıyla birlikte, sunucu yöneticileri bu temaya kendi özel sunucusunu verme kararı almıştır. 
Village; DayZ sunucusu, web sitesi ${ }^{33}$, forum, Discord sunucusu, oyuncuların Twitch ve Youtube kanalları olmak üzere medyalar arası bir alan sunmaktadır. Web sitesi; sunucu bilgisi, haberler, oyuncular, oyundaki farklı oyuncu toplulukları, toplulukların bölgeleri, oyun içindeki telsiz kanalları, kurallar, oyundan alınan ekran görüntüleri gibi yazılı ve görsel materyalleri sunmaktadır. Yine site üzerinden erişilen forumlar, oyun ve sunucuyla ilgili sohbetler, sunucuda gerçekleştirilecek etkinlik önerileri, videolar, oyuncuların oyundaki anıları ve öyküleri, ödül avcıları için aranan haydutlar listesi, çeşitli oyun içi hizmetler sunan oyuncuların ilanları gibi bölümler içermektedir. Discord sunucusu forumlardan farklı olarak acil mesajlaşmaları ve kısa önemsiz yazışmaları mümkün kılmaktadır: Genel konularda sohbetler, haberler, Village konulu sohbetler, oyuncu topluluklarına ait kanallar vb. Bu resmi ortamların yanında yarı-resmi ve sunucuya ait olmayan mecralar da bulunmaktadır. Bunlar arasında Village projesinin yaratıcısı olan ve Barely Infected takma ismini kullanan oyuncunun Youtube kanalı, oyuncuların oyun içinden canlı yayın yaptıkları Twitch kanalları ve videolarını yükledikleri Youtube kanalları sayılabilir.

Village oyun sunucusu kara listeye (black list) sahiptir, yani oyuncular kuralları bozduklarında erişimleri yasaklanmaktadır. Ancak oyuncular hiçbir bilgi sunmaksızın ve kayıt işlemi yapmaksızın sunucuya bağlanabilirler. Sunucunun temel kuralları oyuncuların oyun içindeki isimlerini değiştirmemeleri, sunucuyu kırmaya (hack) çalışmamaları, rol yapmanın gereği dışında diğer oyuncuları rahatsız edecek davranışlardan kaçınmaları ve son olarak da oyuna dahil olan konum bazlı sesli konuşma dışındaki sesli görüşme kanallarını (Teamspeak, Discord veya Steam sesli sohbet vb.) kullanmamalarıdır. Bu kuralları çiğneyenler sunucudan men edilmektedir. Bunun dışında metagaming ${ }^{34}$ (oyun dışındaki çeşitli kanallardan alınan bilgilerle oyunda avantaj elde etmek) de sunucudan atılma nedeni olabilmektedir.

Oyuncu toplulukları zamanla isim değiştirse, bölünse veya bir araya gelerek ittifaklar oluştursa da sunucuda faaliyet gösteren baş aktör Village Guards topluluğudur. Kurucusu sunucunun da yöneticilerinden olan Barely Infected lakaplı oyuncudur. Village Guards 20'ye yakın oyuncudan oluşmaktadır. Oyunda dönüşümlü olarak bulunan sayısı 7'yi bulabilmektedir. Village Guards, daha önce değindiğimiz survivor rolündeki oyunculara yardım etmeye gönüllü üyelerden oluşmaktadır. Village'a yardım istemeye gelen, Village'da sürekli olarak bulunan veya oyun dünyasında karşılaşılan diğer oyuncuları korumak ana görevlerdendir. Village için mekân seçilmesi, bu mekâna yerleşilmesi, düzenlenmesi, konukların karşılanmaSı, onların ihtiyaçlarının giderilmesi, gerektiğinde yeni mekânlara taşınmak, Village için gerekli materyallerin toplanması işleri bu topluluk tarafından yapılmaktadır. Village web sitesinde Village Guards dost topluluklar (friendly factions) altında yer almaktadır, oyunda benimsenen roller açısından ele alındığında kahraman (hero) topluluğu olarak görülebilir.

33 https://barelyinfected.com/

34 Meta oyun (metagaming, oyuncu jargonunda "meta yapmak"), çok farklı şekillerde gerçekleşebilmektedir. Örneğin, canlı yayın suikasti (stream sniping), oyununu twitch.tv gibi kanallardan canlı yayınlayan rakibin yerini öğrenerek, o konuma gidip, hazırlıksız durumda olan rakibi sürpriz bir saldırı ile yenmektir. 
Sunucuda Village Guards dışında Settlement, Queens Guard, RUF gibi çok sayıda topluluk bulunmaktadır. Bu topluluklar genelde kendi kamplarına sahiptir. Settlement gibi bazı gruplar ticaretle uğraşırken, örneğin RUF haydutluk yapan gruplardandır. RUF eylemleri sırasında oyuncuları kaçırıp fidye istemekte, onlara zorla çeşitli komik kıyafetler giydirip, oyun içinde fotoğraflarını çekmektedir.

Village Guards topluluğunun oyuna yaklaşımı, günlük gelişmeler ve sunucunun açılığı tarihten itibaren gelişen olaylar oyun içinde çeşitli kuralların belirlenmesine neden olmaktadır. Örneğin, haydut rolünü sahiplenen bir oyuncu sunucuya bağlanmakta özgürdür, ancak Village mekânına girişi Village Guards tarafından yasaklanabilir. Kazara ölüme neden olanlar, pişmanlık duyanlar ve buna benzer durumdaki oyuncular dışında haydutluk faaliyetlerine kararlı şekilde devam edenlerin görüldükleri yerde öldürülmeleri kararı alınabilir. Bu karara bilgi toplama ve oyunda yapılan rol gereği konuşmalar sonunda varılmaktadır. Bir oyuncunun mikrofona sahip olmaması oyundaki sesli iletişime imkân sağlamadığından, dolayısıyla haydut olup olmadığını belirleyecek gerekli diyaloglar yapılamadığından Village'e girişi yasaklanabilmektedir. DayZ' de bulunan pazu bandı özelliği oyuncu topluluklarının renk kodları kullanmasına imkân tanımaktadır. Village Guards yeşil pazu bandı kullanmaktadır. Haydut gruplarına ait pazu bantlarıyla Village'e giriş kabul edilmemektedir. Yine ziyaretçilerin silahlarını ellerinde tutarak içerde gezinmelerine izin verilmemektedir.

Village mekânı kelimenin Türkçe karşılığına uygun olarak bir köy olmak zorunda değildir. Haydut saldıılarından dolayı sık yer değiştirmek zorunda kalan Village, tarihi bir kalenin içine, fabrikaya, havaalanında bir hangara, radyo istasyonuna da taşınabilmektedir. Her yeni mekân farklı avantajlar ve dezavantajlar barındırdığından, hem saldıran haydutlar için hem de savunan Village Guards üyeleri için yenilikler getirmektedir. Kıyıya uzak lokasyonlar, çatışmalarda ölüp sahilde doğanların Village'a dönmesini zorlaştıııken, kıyıya yakın olanlar da daha çok saldırı almaktadır. Village mekânı değişse de bazı oyuncu davranışları sabit kalmaktadır. Örneğin, geceleyin ateş başında toplanarak sohbet etmek, ateş için odun toplama etkinlikleri vb. Bazı oyuncular kamp ateşi etrafında toplanılan bu anlarda sesli konuşma imkânını seçtikleri çeşitli şarkıları bilgisayarlarından çalmak, hatta bazı zamanlarda enstrümanlarıyla canlı performanslar için kullanmaktadır. DayZ oyununa hâkim kayıp, yalnızlık ve ölüm temaları beraberinde zıddının arayışını, dostluk ve birlik duygusunu getirirken Village bunların gerçekleşmesi için mekân sağlamaktadır.

Village Guards topluluğunda rütbe sistemi bulunmaktadır: Guards, Senior Guards, Guard Captains. Village Guards'a mahsus Discord kanalında bu rütbelerin emir komuta zinciri olarak yorumlanmaması gerektiği, bir şeyi yapmak istemeyen oyuncunun zorlanamayacağı söylenmektedir. Alt rütbelerde Village'a erzak toplanması ve koruma görevleri varken, üst rütbelerde sunucudaki farklı olarak diğer oyuncu toplulukları ile ilişkiler gibi diplomatik görevler de yer almaktadır. Kararların büyük bölümü oy çokluğu ile alınmaktadır.

Guard Captain olarak görev alan Watershed rütbeleri şu şekilde açıklıyor: 
Farklı rütbeler yaratmamızın nedeni daha hızlı karar alabilmek. Guard Captains yerine yöneticiler veya kıdemliler de diyebilirdik. Bazı durumlarda az sayıda kaptanla karar almak, 15 farklı zaman dilimindeki oyuncuları beklemekten daha kolay oluyor ${ }^{35}$ (Kişisel görüşme, 12 Eylül 2019).

Village'da bir oyun günü; gündüz yapılan erzak toplama, iç mekânın düzenlenmesi, inşa çalışmaları, silah temini gibi işleri takiben gece gerçekleşen mekânda ateş yakma ve savunma işleri ile geçmektedir. Yakın bölgelere yapılan erzak toplama turları kimi zaman keyfi kimi zaman da ihtiyaçlar doğrultusundadır. Oyuncuların çeşitli nedenlerle sıkıntıya düştüğü durumlarda onları kurtarmak için operasyonlar düzenlenebilmektedir.

Bazen de yeni oyuncular Village mekânını bulamadıklarında buluşmak ve onları sağ salim ulaştırmak gerekmektedir. Bütün bu işler ortaklaşa yapılmakla birlikte, doğallığı içinde iş bölümü de ortaya çıkabilmektedir. Örneğin, inşa faaliyetlerine veya tarıma gönüllü oyuncular tüm günlerini bununla geçirebilmektedir.

Faaliyetler sırasında Village haydutlar tarafından saldırıya uğrama intimaliyle karşı karşıyadır ve bunun ne zaman gerçekleşeceğini bilmek çoğunlukla mümkün değildir. Saldırı durumları saldıranların etkisiz hale getirilmesi veya kaçması ile son bulabileceği gibi, Village'ın tamamen kaybedilmesi de mümkündür. Bu durum da sıkça yaşanmakta ve mekânın tekrar güvenli hale getirilmesi saatler, hatta günler alabilmektedir. Village'ı koruyanlardan ölenlerin oyuna yeniden başlayıp Village'a ulaşması bile birkaç saat sürebilmektedir. Mekâna geri dönüldüğünde ise çatışma intimali ve yeniden kaybetmek mümkündür. Mekân yeniden kazanıldığında, yapılarda hasarlar ve çalınan eşyalar olması kuvvetle muhtemeldir.

Kayıp oyunun önemli bir parçasıdır: Zamanın, eşyaların, mekânda somutlaşan oyun emeğinin, karakterin yaşamının vb. Kaybı anlamlandırmak sadece ders çıkararak kazanmak için tecrübe elde etme anlamında değil, oyuncuların kendi öykülerinin bir öğesi olarak da değerlidir. Karakterin doğumu ve ölümü arasında tekrarlanan döngü tek perdelik bir oyun gibi tecrübe edilmektedir.

Village Guard Brad kayıp ve ölümün oyundaki duygusal etkisini anlatırken:

Oyundaki her şey epey zaman alıyor, bir şeyleri korumak çaba istiyor, oyunda ölmek gibi basit bir şey bile oldukça sarsıcı. Hiçbir eşya kaybetmemiş olsan bile, geri dönebilmek için ne kadar uzun süre koşacağını bilmek insana koyuyor. Oyunda hiçbir şey kolay değil, her şeyin bir bedeli var. İşler ters gittiğinde kalbin gerçekten deli gibi atıyor, adrenalin yükseliyor ve ne kadar çok şey kaybedeceğini sürekli hissediyorsun ${ }^{36}$ (Kişisel Görüşme, 12 Eylül 2019).

35 Yazar tarafından çevrilmiştir.

36 Yazar tarafından çevrilmiştir. 
DayZ'deki bu topluluk simülasyonunda insanlığın en iyi ve en kötü yanlarının ortaya çıkabildiğini görmekteyiz. Örneğin, bir oyuncu sizi açken görüp yiyecek sunabilmektedir. Öte yandan aynı durumda başka bir oyuncu kendi de aç olduğundan sizi öldürüp yiyeceklerinizi çalabilmektedir. Oyun aracının kendine özgü olanaklarıyla, pek çok toplumsal durum ve etkileşim sürekli üretilmekte ve deneyimlenmektedir.

Village, komün olarak işlemektedir. Oyuncuların bazı özel eşyalarını gömdükleri zulalar olmakla birlikte, mekândaki nesneler ortak kullanıma açıktır. Ziyaretçiler açısından bazı sınırlandırımış alanlar bulunmaktadır, ancak çoğunlukla hayatta kalmayı sağlayacak eşyalara erişim sınırlandırılmamıştır. Oyuncular öldügünde geriye kalan eşyalar saklanmakta ve döndüklerinde geri verilmektedir. Öte yandan çoğu zaman geri dönüş gerçekleşmeyebilir ve geriye kalan eşyalar diğer takım arkadaşları arasında paylaşılabilir.

İlgi çekici noktalardan bir tanesi oyuncuların oyunda olmadıkları zamanlarda, oyun içinde acil durumlar oluştuğunda haberleşip, işlerini bırakarak oyuna girmeleridir. Benzer bir örnek de dünyanın farklı noktalarından oyuna bağlanmış, farklı zaman dilimlerindeki oyuncuların, Village'da ortak bir iş yaparken oyunun gerektirdiklerini hayatın gereklerini yapmaktan öne koymaları ve uykudan, yemekten veya bazen de işlerden feragat etmeleridir.

Village Guard Zach, acil durumlara kendi yaklaşımını şöyle ifade etmektedir: Yapabildiğim kadar erken oyuna girerim. Village'ı her zaman evim, oradaki insanları da ailem olarak gördüm. Anında oyuna giremesem de mümkün olan en kısa zamanda girerim. Hedeflediğimden fazla oyunda kalmak konusuna gelince, elbette oluyor. Normalden fazla durduğum bir sürü zaman oldu. Bazen yardım etmek için, bazen de çok eğlendiğim için ${ }^{37}$ (Kişisel görüşme, 12 Eylül 2019).

Dışardan bir bakışla bu durum oyun bağımlılı̆ı, asosyal davranışlar veya kaçışçוlık (escapism) olarak nitelendirilebilir, öte yandan derinlemesine değerlendirildiğinde oyuncular arasında gelişen arkadaşlık duygusunun oyun dünyasında da olsa gerçek ve değerli olduğunu görmek mümkündür.

Zach oyunlara ve oyunculara yönelik olumsuz değerlendirmelere karşı çıkıyor:

Benim oyun alışkanlıklarımı doğal bulmayan çevremdeki diğer insanlar olmasaydı, muhtemelen bu konuda düşünmezdim bile. Evet, hayatın zorluklarından uzaklaşmak için oynuyorum. Ama oyunda tanıştı̆ıım insanlar hayatımın zor zamanlarında önemli bir yer işgal ettiler. Oyunlar olmazsa onlarla tanışamazdım ve kim bilir, belki de onların yardımları olmasaydı sıkıntılardan kendimi kurtarabilmem daha güç olurdu. Oynamak sıkıntıları azaltmıyor ama arkadaşların yanında işler daha kolay oluyor. Kişisel sıkıntılarımı oyun arkadaşlarımla paylaşıyorum. Beni gerçekten umursuyorlar ve ben de onları. Onlarla maceralara 37 Yazar tarafından çevrilmiştir. 
atılmak, beraber sevdiğimiz bir şey yapmak, gülmek ve eğlenmek, hayatı daha katlanılır kılıyor ${ }^{38}$ (Kişisel görüşme, 12 Eylül 2019).

Bir bakıma oyun dünyasının pikselleri veya byte'ları; çocuk parkının kumları veya beyaz yakalı ofis çalışanının önündeki hesap tablosundaki sayılardan daha az gerçek değiller. Oyun dünyalarında kurulan ilişkilerin fiziksel boyutunun eksikliği, düşünsel veya duygusal anlamda karşıı̆̆ının olmadığı anlamına gelmemektedir. Oyuncular bilgisayar oyunlarında kendi öykülerini yaratıp, oyunlarına anlam katarak hem yaratıcı bir faaliyet içinde bulunmakta hem de sosyal anlamda farklı deneyimler elde etmektedir.

Augusto Boal'ın Ezilenlerin Tiyatrosu anlayışından esinlenen Frasca (2001), bilgisayar oyunlarının farklı toplumsal durumları tartışmaya açmak için, sahnelemeye ve oyuncular tarafından canlandırmaya uygun tasarımlar olarak üretilme imkânı üzerinde durmuştur. Ezilenlerin bilgisayar oyunları olarak adlandırdığı bu yaklaşım forum tiyatrosu tekniklerini oyunlara uyarlamaktadır. Frasca (2000) başka bir çalışmasında, bilgisayar oyunlarının trajik konulara yaklaşabilmesinin bir yolu olarak tek perdelik, kaybedince yeniden oynamanın mümkün olmadığı ya da zor olduğu biçimde tasarlanmalarını önermiştir. DayZ, Frasca'nın bu iki yaklaşımına da uygun bir oyun olarak, insanlığa dair temel ve ciddi konuların canlandırıldığı bir sahne işlevi görmektedir.

\section{Sonuç}

Bu çalışmanın gösterdiği önemli noktalardan ilki; oyun anlatısının bir oyuna ait video ve ekran görüntüleri gibi görsel materyallerin analizi, oyunun tasarımına entegre öyküsünün incelenmesi gibi yöntemlerle ele alınmasının eksik kalacağıdır. Oyunlara dair yapılan araştırmaların büyük bölümü oyun ile şiddet ilişkisi, oyunun eğitim açısından rolü gibi belirli çerçevelere sıkışmış durumdadır. Bu çaIışmaların büyük bölümünde oynanışın derinlikli nitel bir incelemesi yerine içerik analizi yöntemleri oyun medyasına uyarlanma gereği duyulmadan uygulanmaktadır. DayZ gibi yüzeyde şiddet içeren bir oyun, aslında çok sayıda insanın birlikte komünal bir topluluk inşa etme deneyimi gibi farklı olanaklar da sağlayabilmektedir. Oyun araştırmalarında oynanış merkezli, çok boyutlu bir analizin tercih edilmesi araştırmacıları daha verimli sonuçlara götürecektir.

DayZ oyununun oynanışını belirleyen ana unsurlar sınırlandırılmamış PvP, konum bazlı sesli konuşma, hayatta kalma ve kalıcı ölüm oyun mekanikleridir. Bu çalışmada bahsedilen oyun mekaniklerinden yola çıkarak oynanışın nasıl şekillendiğine, buradan da oyuncu rolleri ve davranışlarının nasıl gelişip anlatı olarak neler ortaya çıktığına ulaşılmıştır. Oyun dünyaları ve oynanışın yapılanışı bazı çevrimiçi oyunların çevresinde oyuncu toplulukları oluşmasına ve bunların oyunu da aşan medyalar arası bir kültürel faaliyet içine girmesine olanak vermektedir.

DayZ tasarımıyla çeşitli oyun karakterlerinin öyküsünü anlatmak yerine, binlerce öykü ortaya çıkaran bir toplumsal deney ortamı olarak işlemektedir. Oyuncuları

38 Yazar tarafından çevrilmiştir. 
toplu yok oluşun eşiğinde bir dünyaya koyarak, insanlığın geleceğine dair duygu ve düşünceler uyandırmakta, böyle zamanlardaki toplumsal dinamiklerin bir simülasyonunu sunmaktadır. Bu anlamda Village topluluğu oyuncularının etkinliği bir kaçış değil, kimi zaman gerçeklikte yaşanan sorunların kalbine doğru, yüzleşmeye açık bir yolculuktur. Bunun en açık örneği çoğu Avrupalı olan Village Guards topluluğunun oyunun göçmenleri diyebileceğimiz diğer hayatta kalan oyunculara karşı ne şekilde davranılması gerektiğine dair sürekli bir tartışma içinde olmasıdır. Adorno'nun deyişiyle: "Oyunların gerçekdışılığı, gerçekliğin de henüz gerçek olmadığının işaretidir. Doğru yaşamın bilinçsiz provalarıdır oyunlar" (Adorno, 2005, s. 236).

\section{Kaynakça}

Aarseth, E. (1997). Cybertext: Perspectives on Ergodic Literature. Baltimore and London: The Johns Hopkins University Press.

Aarseth, E. (2003). Playing Research:Methodological Approaches to Game Analysis. Digital Arts \& Culture Conference, Melbourne, 2003. Erişim 1 Haziran 2020, http:// courses.ischool.utexas.edu/megan/MeganCollection2/files/1472/Aarseth.pdf

Aarseth, E. (2007). I Fought the Law: Transgressive Play and The Implied Player. Proceedings of the 2007 DiGRA International Conference: Situated Play. 130133, Erişim 1 Haziran 2020, http://www.digra.org/dl/db/07313.03489.pdf

Adorno, T.W. (2005). Minima Moralia: Sakatlanmış Yaşamdan Yansımalar. İstanbul: Metis Yayınları.

Allison, F. Carter, M. Wadley, G. (2015). Good Frustrations: The Paradoxical Pleasure of Fearing Death in DayZ. Proceedings of the Annual Meeting of the Australian Special Interest Group for Computer Human Interaction, 119-123. Erişim 1 Haziran 2020, https://falsedichotomy2015.files.wordpress.com/2015/09/chiplay2015dichotomy_paper_3.pdf

Backe, H.J. ve Aarseth, E. (2013). Ludic Zombies: An Examination of Zombieizm in Games. Proceedings of the 2007 DiGRA International Conference: Situated Play. Erişim 1 Haziran 2020, http://www.digra.org/wp-content/uploads/digital-library/paper_405.pdf

Bartle, R. (1996). Hearts, Clubs, Diamonds, Spades: Players Who Suit MUDs. The Journal of Virtual Environments, 1(1). Erişim 1 Haziran 2020, https://www. hayseed.net/MOO/JOVE/bartle.html

Bø, K. (2013). Surviving the End. Yayınlanmamış Yüksek Lisans Tezi. University of Tromsø. Erişim 1 Haziran 2020, https://munin.uit.no/bitstream/handle/10037/5274/thesis. pdf? sequence $=2$

Carter, M. Wadley, G. Gibbs, M. (2012). "Friendly, Don't Shoot!": How Communication Design Can Enable Novel Social Interactions. Proceedings of the 24th Australian Computer-Human Interaction Conference, 72-75. Erişim 1 Haziran 2020, 
http://marcuscarter.com/wp-content/uploads/2012/10/DayZ-ozCHI-paper-Final.pdf Carter, M. Gibbs, M. Wadley, G. (2013). Death and Dying in DayZ. Proceedings of The 9th Australasian Conference on Interactive Entertainment: Matters of Life and Death. Erişim 1 Haziran 2020, https://people.eng.unimelb.edu.au/carterm/ Papers/death\%20and\%20dying\%20in\%20DayZ.pdf

Carter, M. Allison F. (2019). Guilt in DayZ. K. Jorgensen ve F. Karlsten, (Ed.), Transgression in Games and Play içinde (133-152). London ve Cambridge: The MIT Press.

Cristofari, C. Guitton, M. J. (2014). Surviving at Any Cost: Guilt Expression Following Extreme Ethical Conflicts in a Virtual Setting. PLoS ONE, 9(7). Erişim 1 Haziran 2020, https://journals.plos.org/plosone/article?id=10.1371/journal.pone.0101711\#s1

Demirbaş, Y. (2017). Oyun Çalışmalarında Dijital Anlatı ile Oyun Biçimi Karşıtığı Ekseninde Süren Tartışmalara Farkıı Bir Bakış. Moment Dergi, 4(2), 352-373, Erişim 1 Haziran 2020, https://dergipark.org.tr/tr/download/article-file/451613

Eskelinen, M. (2001). The Gaming Situation. Game Studies, 1(1). Erişim 1 Haziran 2020, www.gamestudies.org/0101/eskelinen/

Frasca, G. (2000). Ephemeral Games: Is it barbaric to design videogames after Auschwitz?. M. Eskelinen, R. Koskimaa, (Ed.), Cybertext Yearbook 2000 içinde (172-180). Erişim 1 Haziran 2020, https://ludology.typepad.com/weblog/articles/ ephemeralFRASCA.pdf

Frasca, G. (2001). Videogames of the Opressed: Videogames as a Means for Critical Thinking and Debate. Yayınlanmamıs Yüksek Lisans Tezi. Georgia Institute of Technology. Erişim 1 Haziran 2020, http://ludology.typepad.com/weblog/ articles/thesis/FrascaThesisVideogames.pdf

Glas, R. (2010). Games of Stake: Control, Agency and Ownership in World of Warcraft. Özel Basım Doktora Tezi. University of Amsterdam

Harman, S. (21 Ağustos 2012). DayZ's Dean Hall: Rocket Man Rising. Eurogamer. Erişim 1 Haziran 2020, https://www.eurogamer.net/articles/2012-08-21DayZs-dean-hall-rocket-man-rising

Hine, C.M. (2000). Virtual Ethnography. Sage Publications

Holmes, E. (2010). Strange Reality: Glitches and Uncanny Play. Eludamos: Journal for Cumputer Game Culture, 4(2), 255-276. Erişim 1 Haziran 2020, https:// eludamos.org/index.php/eludamos/article/view/vol4no2-9/188

Huizinga, J. (1970). Homo-Ludens: A Study of Play Element in Culture. London: Paladin Jarvinen, A. (2009). Games Without Frontiers: Methods for Game Studies and Design, VDM Verlag

Jones, R. S. (16 Kasım 2018). DayZ has sold 4 million copies. PCGamesN. Erişim 1 Haziran 2020, https://www.pcgamesn.com/DayZ/DayZ-sales-numbers 
Juul, J. (2005). Half-Real: Video Games Between Real Rules and Fictional Worlds. London ve Cambridge: The MIT Press

Karadeniz, Oğuz. (2017). Oyun İncelemelerinde Ludoloji - Narratoloji Tartışması ve Alternatif Kuramsal Arayışlar. Galatasaray Üniversitesi İleti-ş-im Dergisi, (27), 57-78. Erişim 1 Haziran 2020, http://iletisimdergisi.gsu.edu.tr/tr/download/article-file/396144

Klevjer, R. (2002). In Defence of Cutscenes. Computer Games and Digital Cultures Conference Proceedings, 191-202. Tampere University Press.

Kozinetz, R. V. (2010). Netnography: Doing Ethnographic Research Online. Sage Publications.

Lahti, E. (16 Mayıs 2012). Day Z interview - How zombies + Arma 2 created gaming's best story machine. PC Gamer. Erişim 1 Haziran 2020, http://www. pcgamer.com/day-z-interview-how-zombies-arma-2-created-gamings-best-story-machine/

RhinoCRUNCH. (2 Temmuz 2017). Base Build! (Arma 3 DayZ) [Video]. Erişim 1 Haziran 2020, https://www.youtube.com/watch?v=SNHp3HC6_nY\&feature=youtu.be\&t=721

Schmeink, L. (2013). DayZ: Fan-Modification for the Video Game ArmA II. SFRA Review: A publication of the Science Fiction Research Association, 19-20. Erişim 1 Haziran 2020, http://www.sfra.org/resources/sfra-review/303.pdf

Smirnov, A. [_SenChi_]. (18 Kasım 2015). \#DayZ_vs_reality Wooden pub 19th Century, Bulanovo settlement, Tver region. Russia. [Tweet]. Erişim 1 Haziran 2020, https://twitter.com/_SenChi_/status/666996858506604544

Taylor, T.L. (2009). Play Between Worlds: Exploring Game Culture. London ve Cambridge: The MIT Press.

Yee, N. (2007). Motivations of Play in Online Games. Journal of CyberPsychology and Behavior, 9(6), 772-775. Erişim 1 Haziran 2020, http://citeseerx.ist.psu.edu/ viewdoc/download?doi=10.1.1.465.7378\&rep=rep1\&type=pdf

Yengin, D. (2012). Dijital Oyunlarda Şiddet. İstanbul: Beta Yayıncılık.

\section{Ludografi}

Bohemia Interactive. (2009). ARMA 2

Bohemia Interactive. (2010). ARMA 2: Operation Arrowhead

Bohemia Interactive. (2011). Take On Helicopters

Bohemia Interactive. (2018). DayZ

Blizzard Entertainment. (2004). World of Warcraft

Darkpaw Games, (1999). Everquest

Fraxis Games. (2016). XCOM 2

Mojang. (2009). Minecraft 